\title{
Structure and floristic pattern of a coastal dunes in southeastern Brazil
}

\author{
Augusto Giaretta ${ }^{1,3}$, Luis Fernando Tavares de Menezes ${ }^{2}$ and Oberdan José Pereira ${ }^{2}$
}

Submitted: 7 February, 2012. Accepted: 25 October, 2012

\begin{abstract}
The Brazilian shrublands area (restinga) is composed of marine coast vegetation on Quaternary sandy plains, where the species composition can vary depending on the surrounding ecosystems. The aims of this study were to describe the structure and floristic composition of a restinga near the community of Itaúnas, in the northern part of the state of Espírito Santo, to identify any relationships between this restinga and surrounding plant formations, and to determine which are the species that occur preferentially in the coastal forests of Espírito Santo. We sampled woody plants with a diameter at breast height $\geq 2.5 \mathrm{~cm}$, excluding lianas, in 50 plots of $100 \mathrm{~m}^{2}$. We selected studies of coastal forests in the states of Espírito Santo and Bahia to prepare a database that would reveal patterns of floristic variation among these areas. We used two-way indicator species analysis for the identification of the species that occur preferentially in the coastal forests of Espírito Santo. We identified 114 species belonging to 38 families. Species richness was greatest for Myrtaceae (26 species), followed by Fabaceae (10). The Shannon index for the study area was 3.96. The estimated total density was 3,330 individuals/ha and basal area was $32.02 \mathrm{~m}^{2} /$ ha. The highest importance value (IV) was for Protium heptaphyllum (IV, 23.4), indicating that it is characteristic of the Espírito Santo restinga. The results of our floristic analysis indicate that the species composition of the Itaúnas restinga is influenced by the so-called tabuleiro forests (coastal lowland forests on Tertiary deposits), which are most common in northern Espírito Santo. This seems to be the main factor responsible for the gradual reduction in floristic similarity between the restingas in the north of Espírito Santo and those in the south of the state, each constituting a distinct floristic block. In addition, we generated lists of species that occur preferentially in the restinga and tabuleiro forests. Those lists could inform decisions regarding environmental restoration programs.
\end{abstract}

Key words: phytosociology, phytogeography, Pleistocene restinga, Espírito Santo, Itaúnas

\section{Introduction}

One of the major factors responsible for the biological diversity in the Atlantic Forest is its environmental heterogeneity, resulting from significant variations in latitude, longitude and altitude, which function as key determinants of such diversity (Scarano 2002; Marques et al. 2011). Floristic studies conducted along the southeastern coast of Brazil have demonstrated the heterogeneity of the biome as a whole, revealing considerable similarities between forest formations, even those that are geographically distant from each other (Oliveira-Filho \& Fontes 2000). These conclusions were made possible by floristic analyses that considered the Atlantic Forest stricto sensu, despite having been recognized, within a broader approach, as a complex of vegetation patterns, including those distributed on the periphery and classified as associated patterns, such as the shrublands, or restinga (IBGE 1992).
Distributed along the entire coastline of Brazil and therefore the most extensive vegetation type associated with the Atlantic Forest, the restinga is composed of a combination of established vegetation on sandy plains of marine origin formed either during the Quaternary (Menezes \& Araujo 2005) and the Pleistocene, constituting the oldest, innermost portions of the plains, or during the Holocene, constituting the most recent, outermost portions (Martin et al. 1981. Martin et al. 1997). In these environments, the vegetation communities face marked variations in temperature, floods, constant wind, high salinity and nutrient-poor soil, adverse conditions that are reflected in less diversity and structural complexity (Pereira 1990; Scarano 2002; Pimentel et al. 2007). The floristic composition of the restinga can also vary in function of the adjacent ecosystems (Freire 1990; Scherer et al. 2005), acquiring unique characteristics in each region. These characteristics can result in marked floristic and

\footnotetext{
${ }^{1}$ Instituto de Pesquisa Jardim Botânico do Rio de Janeiro, Escola Nacional de Botânica, Programa de Pós-Graduação em Botânica , Rio de Janeiro, RJ, Brazil ${ }^{2}$ Universidade Federal do Espírito Santo, Centro Universitário Norte do Espírito Santo, Laboratório de Ecologia de Restinga e Mata Atlântica, São Mateus, ES, Brazil ${ }^{3}$ Author for correspondence: augustogiaretta@gmail.com
} 
structural differences between geographically proximate areas, creating distinct distribution patterns (Araujo 2000).

Phytogeographically, the restinga in the state of Espírito Santo is characterized by the fact that there is greater floristic similarity between areas of restinga located in the south of the state and those located along the coast of the neighboring state of Rio de Janeiro than between the former and those located in the north of Espírito Santo (Araujo 2000). Floristic studies of the restinga in the southern part of Espírito Santo have indicated that the flora of the adjacent hillside forests have a strong influence (Fabris \& Cesar 1996; Assis et al. 2004b). In fact, the crystalline uplands are closer to the coast in the south of Espírito Santo than in the north of the state. In the north, the most conspicuous geomorphologic feature is constituted by the Tertiary deposits of the Barreiras formation, which extends from the crystalline uplands to near the coastline (Lani et al. 2008). The so-called tabuleiro forests (semi-deciduous, coastal lowland forests) develop on the Barreiras formation, between the restinga and the hillside forests (IBGE 1992; Jesus \& Rolim 2005). Phytophysiognomically, this forest is primarily composed of mata alta (tall forest) vegetation and the so-called muçununga vegetation (similar to that observed in some parts of the restinga). The first, which dominates the landscape, is distributed on clay soils with trees up to 35 feet high, and the second, forming enclaves within the mata alta vegetation, is on sandy soils of marine origin with some trees of small stature and taller trees reaching approximately $10 \mathrm{~m}$ in height (Peixoto et al. 2008; Simonelli et al. 2008).

Considering that the restinga is a geologically recent ecosystem and the colonizing species are from adjacent ecosystems (Freire 1990; Araujo 2000), we can hypothesize that the floristic composition of the restingas in the north of Espírito Santo are influenced by tabuleiro forest and that similarity diminishes toward the south of the state. In this context, the objectives of this study are to describe the structure and floristic composition of an area of Pleistocene restinga in Itaúnas, in northern Espírito Santo; to determine whether relationships exist between the restinga and adjacent floristic formations; and to identify the species that occur preferentially in the coastal forests of the state.

\section{Material and methods}

\section{Study area}

As shown in Fig. 1, the fragment of restinga studied is located on private land in Itaúnas, a district of the municipality of Conceição da Barra, located in the northern part of the state of Espírito Santo ( $\left.18^{\circ} 25^{\prime} 16^{\prime \prime} \mathrm{S} ; 39^{\circ} 43^{\prime} 8^{\prime \prime} \mathrm{W}\right)$, in an area of 51.3 ha and a border along the edge of the Itaúnas State Park, lying approximately $2 \mathrm{~km}$ from the coastline. The forest studied is associated with fields of Pleistocene sand ridges (Kenitiro Suguio, personal communication) that were formed after the peak of the penultimate marine transgression, initiated at approximately 123,000 B.C., when the relative sea level was $8 \pm 2 \mathrm{~m}$ higher than the present-day level (Suguio \& Martin 1978; Suguio et al. 1982). The dune ridge extends approximately $10 \mathrm{~m}$ above sea level, without any waterlogging of the soil due to fluctuations in the groundwater level. The soil is composed of a surface layer of leaf litter $\leq 15 \mathrm{~cm}$ deep; $5 \mathrm{~cm}$ further down, there is a network of thin, intertwined roots, below which there is sandy sediment, the initial layer of which is white. The closest weather station is located in the municipality of São Mateus, approximately $35 \mathrm{~km}$ from the study area. Climatic data recorded over the last 34 years by the Espírito Santo State Institute for Research, Technical Support and Rural Extension Services/National Meteorology Institute show that average annual temperature ranges from $21.7^{\circ} \mathrm{C}$ to $26.7^{\circ} \mathrm{C}$, with a relative humidity of $83 \%$ and an average annual rainfall of $1308 \mathrm{~mm}$. According to the Köppen climate classification system, the study area climate is type Aw (tropical savanna), a humid tropical climate in which rainfall rates are highest during the summer months and lowest during winter months.

\section{Vegetation sampling}

Data were collected on 0.5 ha of restinga in Itaúnas, divided into 50 plots of $10 \times 10 \mathrm{~m}$ (Müeller-Dombois \& Ellenberg 1974). The plots were delineated systematically with use of a compass in 11 rows in a northwest-southeast orientation, providing the basis for implementation of alternately positioned plots at least $50 \mathrm{~m}$ apart.

We sampled all woody plants, except lianas, with a diameter at breast height $(\mathrm{DBH}) \geq 2.5 \mathrm{~cm}$, including dead and standing trees. For each sampled individual, we also estimated height with the aid of a pole pruner of known length $(6 \mathrm{~m})$. Individuals profiled above ground level and with a $\mathrm{DBH}<2.5 \mathrm{~cm}$ were marked and measured when one of the branches fit the inclusion criteria, with measurements from all branches then recorded to calculate the basal area. The floristic list was supplemented with individuals collected outside the plots, following the inclusion criteria established for the structural analysis.

All fertile material collected was categorized according to Fidalgo \& Bononi (1984) and incorporated into the collection of the Central Herbarium of the Federal University of Espírito Santo (VIES). The botanical identifications were performed by consulting classical works and taxonomic reviews, as well as through expert consultation and by comparisons with material on file at the Central Herbarium of the Federal University of Espírito Santo, the Natural Vale Reserve Herbarium and the Herbarium of the Rio de Janeiro Botanical Gardens. The taxonomic classification system used was that proposed by the Angiosperm Phylogeny Group (APG III 2009). For the abbreviations of the authorities for specific binomials, we followed the example of Brummitt \& Powell (1992). 


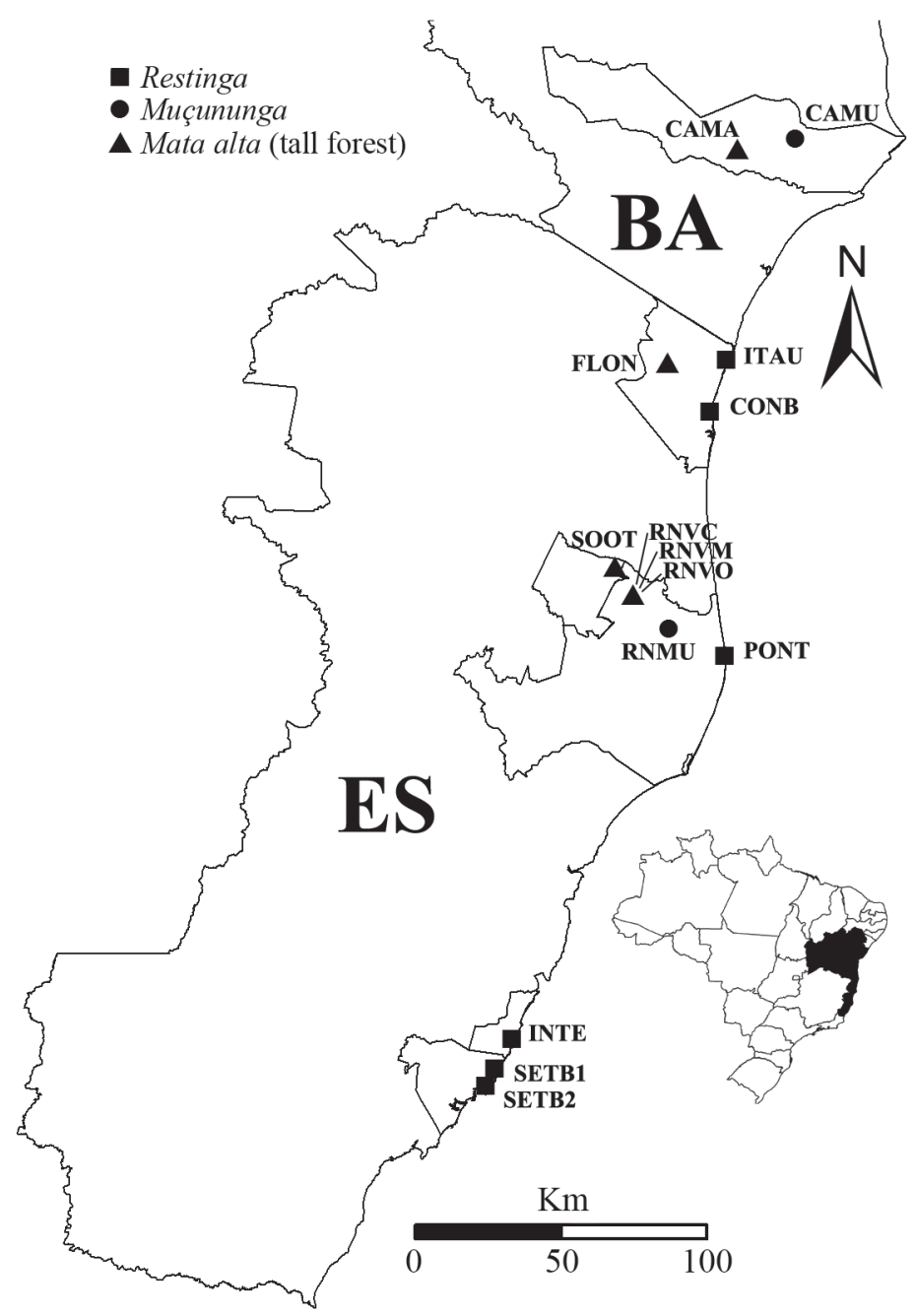

Figure 1. Location of the study area and distribution of sites used in the floristic analyses of the coastal forests in the state of Espírito Santo and in the southern part of the state of Bahia, Brazil.

Restinga - shrublands; muçununga - similar to restinga but established on Tertiary land, forming enclaves in the mata alta (tall forest).

\section{Vegetation structure}

To evaluate the vertical structure, we used the absolute and relative phytosociological parameters described in Brower \& Zar (1984). We chose to use the Shannon diversity index $\left(\mathrm{H}^{\prime}\right)$ and Pielou's evenness index $\left(\mathrm{J}^{\prime}\right)$.

To analyze the vertical stratification of the forest, we developed an abundance matrix, organizing the sampled individuals into 1-m classes by height. To determine whether our sample was floristically representative of the vegetation formation, we performed a sampling sufficiency analysis using Mao Tau rarefaction curves, with a confidence interval of $95 \%$ (Colwell et al. 2004), and an abundance matrix by plots, calculated with the program PAST, version 2.0 (Hammer et al. 2001). This method consists in sorting the order of entry of the plots or individuals and calculation of the cumulative number of species, thus avoiding the influence that the randomness of the order of the sampling units might have on the construction of the curve (Kersten \& Galvão, 2011).

\section{Similarity analysis}

For the similarity analysis, we included data from 14 floristic and phytosociological studies conducted areas in that were in a good state of conservation, including the present study, totaling 669 shrub or tree species (Fig. 1). For restingas and tabuleiro forests (Tab. 1), we included mostly studies conducted in Espírito Santo, the exceptions being two studies conducted in the southern part of the state of Bahia. The forest referred to here as the muçununga of Caravelas, in Bahia, is, phytophysiognomically, a poorly drained system (Meira-Neto \& 2005). Nevertheless, we treated it in a broader context, in order to elucidate floristic differences in comparison with the muçununga forest in Espírito Santo. The 14 studies selected were used in order to compile a binary matrix (presence vs. absence) of tree and shrub species occurring in those two areas, considering only the specific level determinations and verified synonyms in the database from the list of species 
Table 1. Information about the sites used in the floristic analyses of 14 coastal forests in the state of Espírito Santo and in the southern part of the state of Bahia, Brazil.

\begin{tabular}{|c|c|c|c|c|c|c|c|c|}
\hline Abbreviation & Location & Municipality & Reference & Vegetation formation & Method & Area & $\begin{array}{l}\text { Inclusion } \\
\text { criterion }\end{array}$ & $\mathrm{H}^{\prime}$ \\
\hline SETB1 & $\begin{array}{l}\text { Paulo César Vinha } \\
\text { State Park* } 1\end{array}$ & Guarapari (ES) & Assis et al. 2004b & Restinga & $\mathrm{P}$ & 1 ha & $\mathrm{DBH} \geq 4.8 \mathrm{~cm}$ & 3.73 \\
\hline SETB2 & $\begin{array}{l}\text { Paulo César Vinha } \\
\text { State Park } 2\end{array}$ & Guarapari (ES) & Fabris \& César 1996 & Restinga & $\mathrm{P}$ & 0.5 ha & $\mathrm{DBH} \geq 4.8 \mathrm{~cm}$ & - \\
\hline INTE & Interlagos & Vila Velha (ES) & $\begin{array}{c}\text { Pereira \& Zambom } \\
1998\end{array}$ & $\begin{array}{c}\text { Restinga/dry tropical } \\
\text { forest }\end{array}$ & $\mathrm{F}$ & - & - & - \\
\hline PONT & Pontal do Ipiranga & Linhares (ES) & Pereira et al. 1998 & $\begin{array}{l}\text { Restinga/dry tropical } \\
\text { forest }\end{array}$ & $\mathrm{F}$ & - & - & - \\
\hline ITAU & Itaúnas & $\begin{array}{l}\text { Conceição da } \\
\text { Barra (ES) }\end{array}$ & The present study & Restinga & $\mathrm{P}$ & 0.5 ha & $\mathrm{DBH} \geq 2.5 \mathrm{~cm}$ & 3.96 \\
\hline CONB & Conceição da Barra & $\begin{array}{c}\text { Conceição da } \\
\text { Barra (ES) }\end{array}$ & Pereira \& Gomes 1994 & $\begin{array}{c}\text { Restinga/Myrtaceae- } \\
\text { dominated dry } \\
\text { tropical forest }\end{array}$ & $\mathrm{F}$ & - & - & - \\
\hline RNMU & $\begin{array}{l}\text { Rio Doce Valley } \\
\text { Nature Reserve }\end{array}$ & Linhares (ES) & Simonelli et al. 2008 & Muçununga & $\mathrm{P}$ & $0.93 \mathrm{ha}$ & $\mathrm{DBH} \geq 5 \mathrm{~cm}$ & 3.36 \\
\hline CAMU & Caravelas & Caravelas (BA) & Meira-Neto et al. 2005 & Muçununga & $\mathrm{F}$ & - & - & - \\
\hline CAMA & Caravelas & Caravelas (BA) & Souza et al. 1998 & Mata alta & $\mathrm{P}$ & 1.125 ha & $\mathrm{DBH} \geq 5 \mathrm{~cm}$ & 4.71 \\
\hline FLON & $\begin{array}{l}\text { Rio Preto National } \\
\text { Forest }\end{array}$ & $\begin{array}{c}\text { Conceição da } \\
\text { Barra (ES) }\end{array}$ & Salomão 1998 & Mata alta & $\mathrm{P}$ & 10.55 ha & $\mathrm{DBH} \geq 10 \mathrm{~cm}$ & 4.71 \\
\hline SOOT & $\begin{array}{l}\text { Sooretama Biological } \\
\text { Reserve }\end{array}$ & Sooretama (ES) & Paula \& Soares 2011 & Mata alta & $\mathrm{P}$ & 1 ha & $\mathrm{DBH} \geq 4.8 \mathrm{~cm}$ & 4.87 \\
\hline RNVC & $\begin{array}{l}\text { Caigá Valley Nature } \\
\text { Reserve }\end{array}$ & Linhares (ES) & Jesus \& Rolim 2005 & Mata alta & $\mathrm{P}$ & 24 ha & $\mathrm{DBH} \geq 4.8 \mathrm{~cm}$ & 4.98 \\
\hline RNVM & $\begin{array}{l}\text { Macanaíba Valley } \\
\text { Nature Reserve }\end{array}$ & Linhares (ES) & Jesus \& Rolim 2005 & Mata alta & $\mathrm{P}$ & $9.6 \mathrm{ha}$ & $\mathrm{DBH} \geq 4.8 \mathrm{~cm}$ & 4.83 \\
\hline RNVO & $\begin{array}{l}\text { Oiticica Valley } \\
\text { Nature Reserve }\end{array}$ & Linhares (ES) & Jesus \& Rolim 2005 & Mata alta & $\mathrm{P}$ & 6.4 ha & $\mathrm{DBH} \geq 4.8 \mathrm{~cm}$ & 4.79 \\
\hline
\end{tabular}

${ }^{\star}$ Formerly known as Setiba Park, hence the abbreviation.

Restinga - shrublands; muçununga - similar to restinga but established on Tertiary land, forming enclaves in the mata alta (tall forest); P - Plot; DBH - diameter at breast height; $\mathrm{F}$ - Floristics; H' - Shannon diversity index.

of Flora of Brazil (http://floradobrasil.jbrj.gov.br/2012/). This same data set was the basis for the analyses to follow. To calculate similarity, we used the Sørensen coefficient (Müeller-Dombois \& Ellenberg 1974), because it is more effective than are other similarity measures, as well as being consistent with the unweighted pair group method with arithmetic mean (McCune Grace \& 2002; Magurran 2004), which is employed in order to avoid distortions during the analysis (McCune \& Mefford 1999). For all cluster analyses, we used the Multivariate Statistical Package, version 3.1 (Kovach 2004). To identify species that occur preferentially in the coastal forests of Espírito Santo and were responsible for the clusters formed in the similarity dendrogram, we used dichotomous classification by Two-Way Indicator Species Analysis (TWINSPAN; Hill 1979). In order to rank the areas according to the floristic similarity and thus reveal patterns of variation in species composition along an environmental gradient (ter Braak
1995), we performed reciprocity averaging, equivalent to a correspondence analysis, the latter name being chosen due to its wider usage. These analyses were processed with the program PC-ORD, version 4.1 (McCune \& Mefford 1999).

\section{Results}

\section{Floristics, structure and diversity}

The survey of trees and shrubs revealed the presence of 114 species, within 96 genera, among 38 families. The richest families were Myrtaceae (27 species, 23.7\%), Fabaceae (10 species, $8.8 \%$ ), Sapotaceae ( 8 species, $7 \%$ ), Lauraceae (7 species, 6\%) Annonaceae, Rubiaceae and Rutaceae (4 species each, 3.5\% each), collectively representing 56.0\% of the species sampled and $68.2 \%$ of the samples of living individuals. Samples collected from outside the study area (146 species) added 32 species to the floristic list (Tab. 2). 
Table 2. Floristic list of shrub/tree species occurring in the restinga (shrublands) in Itaúnas, near the municipality of Conceição da Barra, in the state of Espírito Santo, Brazil.

\begin{tabular}{|c|c|}
\hline Family & Species \\
\hline Achariaceae & Carpotroche brasiliensis (Raddi) Endl. \\
\hline \multirow{3}{*}{ Anacardiaceae } & Schinus terebinthifolius Raddi \\
\hline & Spondias macrocarpa Engl. \\
\hline & Tapirira guianensis Aubl. \\
\hline \multirow{5}{*}{ Annonaceae } & Annona salzmannii A. DC. \\
\hline & Duguetia sessilis (Vell.) Maas \\
\hline & Unonopsis aurantiaca Maas \& Westra \\
\hline & Xylopia laevigata R.E. Fr.* \\
\hline & Xylopia sericea A. St.-Hil. \\
\hline \multirow{4}{*}{ Apocynaceae } & Aspidosperma pyricollum Müll. Arg. \\
\hline & Himatanthus phagedaenicus (Mart.) Woods. \\
\hline & Rauvolfia mattfeldiana Markgr.* \\
\hline & Tabernaemontana flavicans Willd. ex Roem. \& Schult.* \\
\hline \multirow{2}{*}{ Bignoniaceae } & Jacaranda puberula Cham.* \\
\hline & Tabebuia roseoalba (Ridl.) Sandwith \\
\hline Boraginaceae & Cordia taguahyensis Vell.* \\
\hline Brassicaceae & Capparis flexuosa (L.) L.* \\
\hline \multirow{3}{*}{ Burseraceae } & Protium heptaphyllum (Aubl.) Marchand \\
\hline & Protium icicariba (DC.) Marchand \\
\hline & Trattinnickia mensalis Daly \\
\hline \multirow{2}{*}{ Calophyllaceae } & Kielmeyera albopunctata Saddi \\
\hline & Kielmeyera membranacea Casar. \\
\hline Caricaceae & Jacaratia heptaphylla (Vell.) A. DC.* \\
\hline \multirow{2}{*}{ Celastraceae } & Maytenus cf. communis Reissek \\
\hline & Maytenus distichophylla Mart. \\
\hline \multirow{4}{*}{ Chrysobalanaceae } & Couepia schottii Fritsch \\
\hline & Couepia sp. \\
\hline & Licania heteromorpha Benth. \\
\hline & Licania arianeae Prance ${ }^{*}$ \\
\hline \multirow{2}{*}{ Clusiaceae } & Clusia hilariana Saddi \\
\hline & Garcinia brasiliensis Mart. \\
\hline Connaraceae & Connarus blanchetti Planch. \\
\hline Ebenaceae & Diospyros apeibacarpos Raddi $^{*}$ \\
\hline Elaeocarpaceae & Sloanea guianensis (Aubl.) Benth. \\
\hline Erythroxylaceae & Erythroxylum subsessile (Mart.) O.E. Schulz \\
\hline Euphorbiaceae & Joannesia princeps Vell. \\
\hline
\end{tabular}


Table 2. Continuation.

\begin{tabular}{|c|c|}
\hline Family & Species \\
\hline \multirow{13}{*}{ Fabaceae } & Abarema filamentosa (Benth.) Pittier \\
\hline & Acosmium bijugum (Vogel) Yakovlev* \\
\hline & Andira fraxinifolia Benth. \\
\hline & Andira nitida Mart. ex Benth. \\
\hline & Chamaecrista ensiformis (Vell.) H.S. Irwin \& Barneby* \\
\hline & Inga exfoliata T.D. Penn. \& F.C.P. García \\
\hline & Inga laurina $($ Sw.) Willd.* \\
\hline & Inga subnuda Salzm. ex Benth. \\
\hline & Macrolobium latifolium Vogel \\
\hline & Pterocapus rohrii Vahl \\
\hline & Swartzia apetala Raddi \\
\hline & Swartzia simplex (Sw.) Spreng. \\
\hline & Zollernia glabra (Spreng.) Yakovlev. \\
\hline Humiriaceae & Humiriastrum dentatum (Casar.) Cuatrec. \\
\hline Icacinaceae & Emmotum nitens Miers. \\
\hline Lacistemaceae & Lacistema robustum Schnizl. \\
\hline \multirow[t]{4}{*}{ Lamiaceae } & Vitex polygama Cham. \\
\hline & Aiouea saligna Meisn. \\
\hline & Aniba firmula (Ness \& Mart.) Mez \\
\hline & Ocotea glaziovii Mez \\
\hline \multirow[t]{4}{*}{ Lauraceae } & Ocotea lobbii (Meisn.) Rohwer \\
\hline & Ocotea notata (Nees \& C. Martius ex Nees) Mez \\
\hline & Ocotea sp. 1 \\
\hline & Ocotea sp.2 \\
\hline Lecythidaceae & Eschweilera ovata (Cambess.) Miers \\
\hline \multirow{2}{*}{ Malpighiaceae } & Byrsonima bahiana W.R. Andreson \\
\hline & Byrsonima sericea DC. \\
\hline \multirow[t]{2}{*}{ Malvaceae } & Eriotheca macrophylla (K. Schum.) A. Robyns \\
\hline & Miconia cf. cinnamomifolia (DC.) Naudim* \\
\hline \multirow[t]{2}{*}{ Melastomataceae } & Miconia prasina (Sw.) DC.* \\
\hline & Miconia cf. pusilliflora (DC.) Naudin \\
\hline Meliaceae & Guarea penningtoniana Pinheiro \\
\hline \multirow[t]{3}{*}{ Monimiaceae } & Mollinedia glabra (Sprengel) Perkins.* \\
\hline & Ficus cf. bahiensis C.C. Berg \& Carauta \\
\hline & Ficus gomelleira Kunth \& C.D. Bouché \\
\hline \multirow[t]{3}{*}{ Moraceae } & Ficus tomentella (Miq.) Miq.* \\
\hline & Ficus cf. trigona L.f. \\
\hline & Sorocea hilarii Gaudich.* \\
\hline
\end{tabular}


Table 2. Continuation.

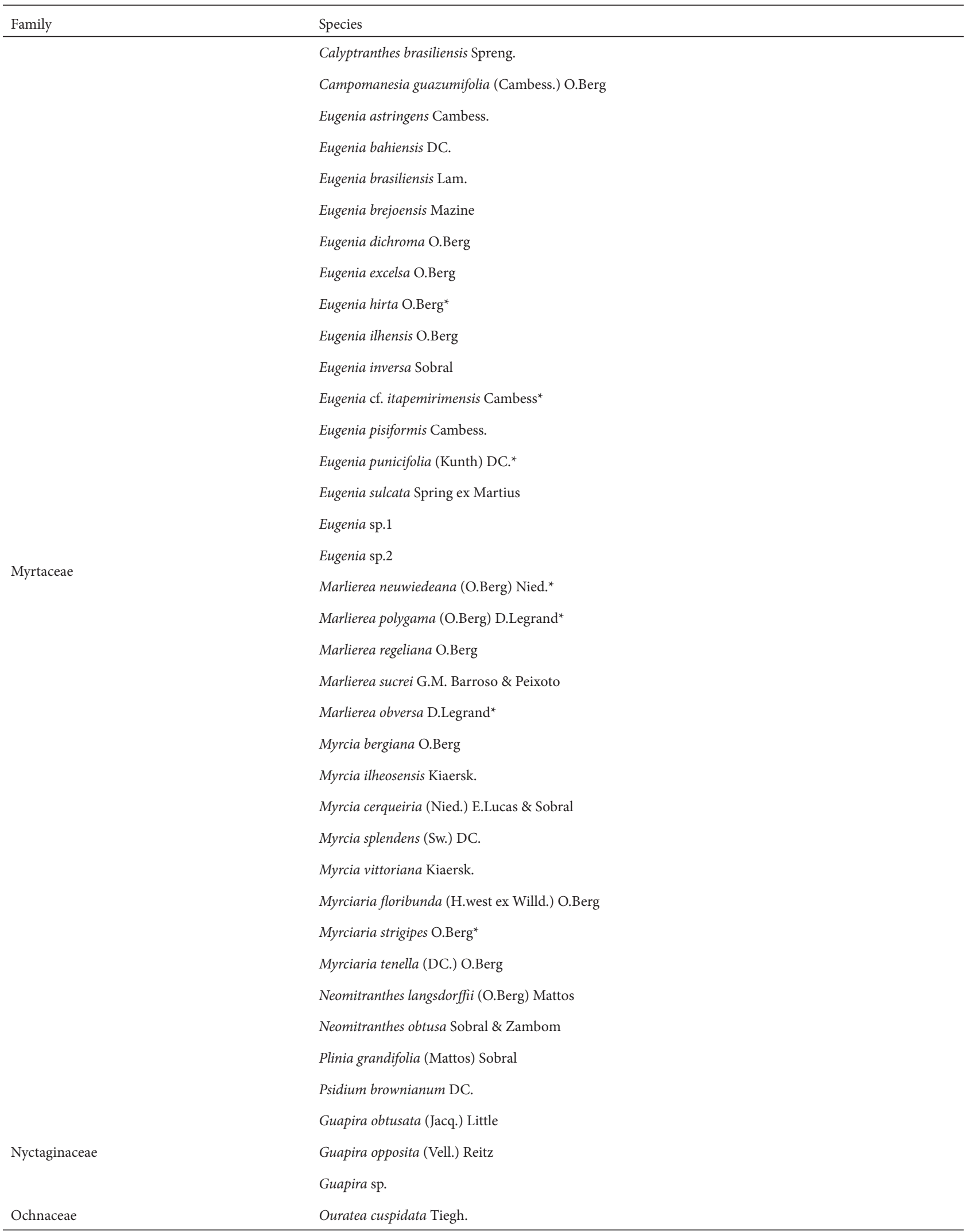


Table 2. Continuation.

\begin{tabular}{|c|c|}
\hline Family & Species \\
\hline \multirow[t]{2}{*}{ Olacaceae } & Heisteria perianthomega (Vell.) Sleumer \\
\hline & Pera glabrata Baill. \\
\hline \multirow[t]{2}{*}{ Peraceae } & Pera leandri Baill. \\
\hline & Pogonophora schomburgkiana Miers ex Benth. \\
\hline Picramniaceae & Picramnia gardneri Planch. \\
\hline \multirow[t]{3}{*}{ Primulaceae } & Myrsine guianensis (Aubl.) Kuntze \\
\hline & Amaioua intermedia Mart. \\
\hline & Chiococca nitida Benth.* \\
\hline \multirow[t]{6}{*}{ Rubiaceae } & Melanopsidium nigrum Colla \\
\hline & Psychotria carthagenensis Jacq. \\
\hline & Simira glaziovii (K. Schum.) Steyerm. \\
\hline & Conchocarpus insignis Pirani* \\
\hline & Conchocarpus longifolius (A.St.-Hil.) Kallunki \& Pirani \\
\hline & Esenbeckia grandifolia Mart. \\
\hline \multirow{3}{*}{ Rutaceae } & Pilocarpus grandiflorus Engl. \\
\hline & Rauia cf. nodosa (Engl.) Kallunki \\
\hline & Ravenia infelix Vell.* \\
\hline \multirow[t]{2}{*}{ Salicaceae } & Casearia commersoniana Cambess. \\
\hline & Cupania emarginata Cambess. \\
\hline \multirow[t]{6}{*}{ Sapindaceae } & Cupania racemosa (Vell.) Radlk. \\
\hline & Matayba guianensis Aubl. \\
\hline & Chrysophyllum splendens Spreng. \\
\hline & Manilkara subsericea (Mart.) Dubard \\
\hline & Micropholis venulosa (Mart. \& Eichler) Pierre \\
\hline & Pouteria caimito (Ruiz \& Pav.) Radlk. \\
\hline \multirow{4}{*}{ Sapotaceae } & Pouteria coelomatica Rizzini \\
\hline & Pouteria grandiflora (A. DC.) Baehni \\
\hline & Pouteria peduncularis (Martius \& Eichler) Baehni \\
\hline & Pouteria aff. psammophila (Mart.) Radlk. \\
\hline \multirow[t]{2}{*}{ Simaroubaceae } & Simarouba amara Aubl. \\
\hline & Aureliana fasciculata (Vell.) Sendtn* \\
\hline \multirow[t]{2}{*}{ Solanaceae } & Cestrum retrofractum Dunal ${ }^{*}$ \\
\hline & Solanum martii Sendtn.* \\
\hline Urticaceae & Cecropia pachystachya Trécul. \\
\hline
\end{tabular}

*Species outside the complementary sampling of the floristic list.

The most numerous genera were Eugenia (15 species), Marlierea, Myrcia, Ocotea and Pouteria (5 species each).

The mean height of the forest was $8 \pm 4 \mathrm{~m}$, the lower stratum comprising individuals $2-3 \mathrm{~m}$ in height (Fig. 2) and accounting for $44.7 \%$ of all sampled species. The most representative species, in terms of the numbers of individuals, were Unonopsis aurantiaca, Ocotea lobbii, Myrcia vittoriana, Eugenia astringens and Ouratea cuspidata. These species collectively accounted for $7.5 \%$ of the individuals and $0.8 \%$ of the total basal area. The middle stratum comprised individuals $4-9 \mathrm{~m}$ in height, accounting for $76.2 \%$ of all sampled individuals, $92 \%$ of the species and 


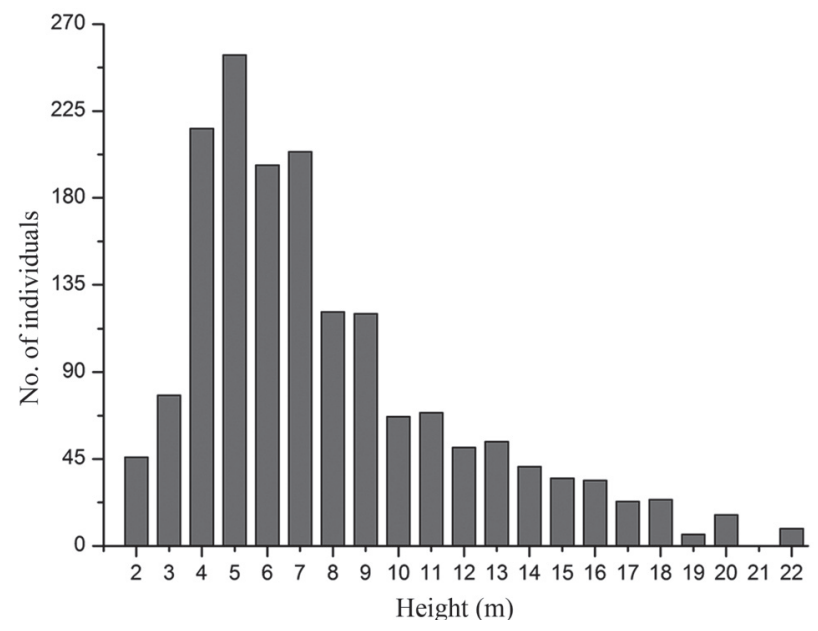

Figure 2. Distribution of frequencies of classes of total height $(\mathrm{m})$ of the individuals in the restinga (shrublands) in Itaúnas, near the municipality of Conceição da Barra, in the state of Espírito Santo, Brazil.

$17.6 \%$ of the total basal area, O. lobbii, U. aurantiaca, M. vittoriana, E. excelsa and E. astringens showing the greatest density in this stratum. Individuals in the upper stratum (10-22 $\mathrm{m}$ in height) accounted for $16.7 \%$ of the species, the tallest individuals being those of Protium heptaphyllum, Tapirira guianensis, Kielmeyera albopunctata, Macrolobium latifolium and Aspidosperma pyricollum. Upper-stratum species accounted for $25.8 \%$ of the individuals sampled and covered $81.6 \%$ of the total basal area.

The behavior of the species-area rarefaction curve indicated a tendency towards stabilization, given that, by the time half of the allocated plots had been sampled, approximately $85 \%$ of the species had been included (Fig. 3). Of the 114 species sampled, 20 (17.5\%) were represented by a single individual.

In Itaúnas, the H' was 3.96 and the J' was 0.836 . Among trees and bushes, we sampled 1665 living individuals, collectively covering a basal area of $32.02 \mathrm{~m}^{2} /$ ha. We recorded 107 dead individuals totaling $1.10 \mathrm{~m}^{2} / \mathrm{ha}$ basal area, with $65.5 \%$ of individuals with $\mathrm{DBH} \leq 5 \mathrm{~cm}$ and $24 \% \leq 10 \mathrm{~cm} \mathrm{DBH}$. As can be seen in Tab. 3, Burseraceae and Anacardiaceae stood out in that they accounted for a considerable portion of the basal area mainly because of a single species. P. heptaphyllum occupied $10.4 \%$ of the total basal area, accounting for $64.5 \%$ of the basal area covered by Burseraceae, and T. guianensis occupied $6.1 \%$ of the total basal area, accounting for $98.2 \%$ of the basal area covered by Anacardiaceae. Myrtaceae was the most important family, accounting for $16 \%$ of the total importance value (IV), E. astringens and E. excelsa showing IVs of 10.8 and 9.9, respectively (Tab. 4).

Taking all of the phytosociological information, as well as the floristic composition and the soil water saturation, into account, we can classify the forest formation analyzed as a dune-ridge forest, according to the classification system devised by Menezes \& Araujo (2005) and Silva \& Britez (2005).

\section{Similarity analysis}

The similarity coefficient between the coastal forests of Espírito Santo and those of southern Bahia ranged from 0.03 to 0.86 , which, by TWINSPAN, could indicate that some species were preferential to these forests (Chart 1). According to the similarity dendrogram (Fig. 4), restingas constitute a cohesive cluster associated by a similarity coefficient ranging from 0.27 to 0.57 , with only Capparis flexuosa, Garcinia brasiliensis, P. heptaphyllum and Guapira opposita occurring in all of the restingas considered. Within the cluster consisting of restingas, one subcluster comprised restingas in northern Espírito Santo (Conceição da Barra and Itaúnas) and another comprised restingas in the southern and northern parts of the state (Interlagos, as well as two locations with the Paulo César Vinha State Park, previously known as Setiba Park, in the south; and Pontal do Ipiranga in the north).

The floristic similarity between the restinga of Itaúnas and the other restingas analyzed ranged from 0.29 to 0.43 , varying even when compared with the survey conducted in Conceição da Barra (Gomes Pereira \& 1994), which is quite near our study area. Nevertheless, Itaúnas and Conceição da Barra proved to be cohesive in the similarity analysis and consistent in the TWINSPAN divisions (eigenvalue, 0.499), Eriotheca macrophylla, Ficus gomelleira, Joannesia princeps, M. latifolium and Pterocarpus rohrii being identified as responsible for this clustering. Given the floristic similarities between the restinga of Itaúnas and the other formations evaluated (0.08-0.43), the Itaúnas restinga, as would be expected, showed greater affinity with the other restingas. However, despite the low degree of floristic affinity between the Itaúnas forest and the tabuleiro forests (0.150.22 ), Itaúnas was more similar to the tabuleiro forest than to the other restingas analyzed (0.04-0.16).

According to the similarity dendrogram, the muçununga forest in Linhares (Rio Doce Valley Nature Reserve) had greater floristic affinity with the restinga. The muçununga forest in Caravelas constituted an outlier to all of the other forests analyzed, with a similarity coefficient of 0.06 .

Floristically, the areas of mata altaformed a very cohesive cluster, generating the highest similarity indices (0.46-0.86). Although the mata alta in Caravelas (southern Bahia) is geographically the most remote of the mata alta surveyed, the mata alta in the Sooretama Biological Reserve showed the least similarity.

The correspondence analysis eigenvalues for the first two axes were 0.739 and 0.604 for axis 1 and axis 2, respectively, the first explaining $17.88 \%$ of the total variance, compared with $14.63 \%$ for the second, collectively explaining $32.51 \%$. Therefore, the ordination diagram distinguished a cluster that was highly associated by the proximity among the mata alta areas (Fig. 5). The restingas formed another cluster, which, unlike the mata alta areas, comprised formations that were more or less aligned in order. Along axis 1 , the muçununga forests were in an intermediate position 


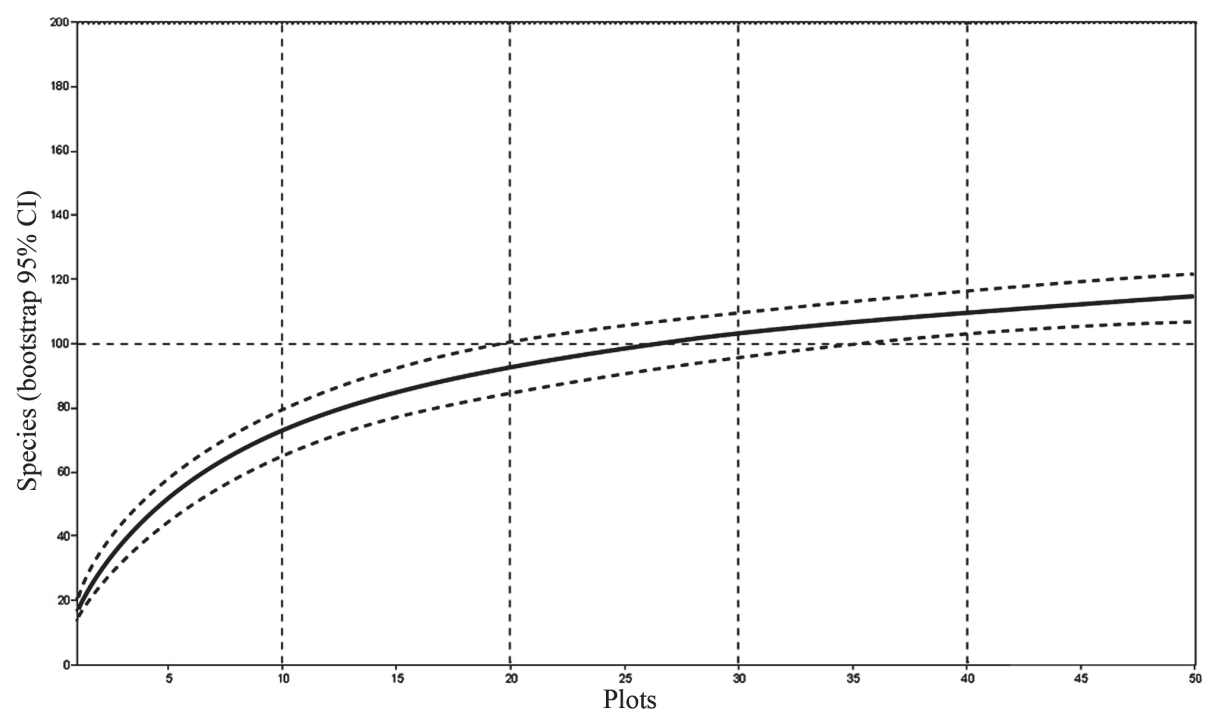

Figure 3. Species-area rarefaction curve, generated with the Mao Tau method, for the restinga (shrublands) in Itaúnas, near the municipality of Conceição da Barra, in the state of Espírito Santo, Brazil.

$\mathrm{CI}$ - confidence interval.

between restinga and mata alta. According to axis 2, the muçununga forest in Caravelas was floristically distant from the other forests.

\section{Discussion}

\section{Floristics, structure and diversity}

In floristic surveys of shrub or tree formations in well-drained restingas in northern Espírito Santo, 82 species have been observed in Linhares (Pereira et al. 1998), comparable to the 83 observed in Conceição da Barra (Pereira \& Gomes 1994). In the cities of Vila Velha (Pereira \& Zambom 1998) and Guarapari (Assis et al. 2004a), coastal communities in the south of the state, 74 and 103 species, respectively, were observed. In the state of Rio de Janeiro, which has the longest tradition of studying restinga communities, species richness has been shown to range from 26 to 108 species (Assumpção \& Nascimento 2000; Lobão \& Kurtz 2000; Sá \& Araujo 2009). The Itaúnas forest presented even higher species richness, indicating that it is an important forest remnant that should be preserved.

The great species richness of Myrtaceae is commonly known and has also been detected in other restingas along the Brazilian coast (Araujo 2000; Assumpção \& Nascimento 2000; Scherer et al. 2005; Sacramento et al. 2007; Amaral et al. 2008). This might be related to the adaptability of Myrtaceae species to low fertility soils (Ashton 1988), such as those of the restinga (Scarano 2002).

The high species richness of the Itaúnas restinga is attributable to the presence of families that are also plentiful in other neotropical formations (Leitão-Filho 1987). Along the southern coast of Brazil, where Waechter et al. (2000) and
Guedes et al. (2006) each found only one Sapotaceae species (Sideroxylon obtusifolium (Roem. \& Schult.) T.D. Penn. and Manilkara Subsericea, respectively), Sapotaceae is the family that has had the highest VI. Along the northern and northeastern coasts, Sapotaceae is also not among the most species-rich families, only four species or fewer having been observed (Freire 1990; Sacramento et al. 2007; Santos-Filho et al. 2011). Studies addressing the structural contribution of these species in the communities of the northern and northeastern Brazil are scarce, which precludes comparisons across studies. On the coast of the state of São Paulo, in southeastern Brazil, Guedes et al. (2006) found that a single Sapotaceae species was the most important species in a flooded restinga and the fifth most important in a terra firme forest. In the restinga within Paulo César Vinha State Park, on the southern coast of Espírito Santo, Assis et al. (2004b) found that the Sapotaceae family was also important, $\mathrm{Pou}$ teria coelomatica having the second highest IV. Unlike the authors of the aforementioned studies, those authors also found Sapotaceae to be one of the most species-rich families, being represented by nine species. Similarly, in that study, Sapotaceae stood out for its contribution to the structure and species richness of the community. Sapotaceae has also been identified as being among the most species-rich families in the restinga in the state of Rio de Janeiro (Pereira \& Araujo 2000). Given its wide distribution along the Brazilian coast, Sapotaceae can also be considered characteristic of nutrient-poor soils such as that of the restinga. In the northern and northeastern regions, with the data currently available, Sapotaceae can be identified as being of key importance for the flora of the restinga forests. For the southern and southeastern regions, Sapotaceae is of relevant structural importance. In the southeast, Sapotaceae plays an important role in the flora and structure of restinga forests in the 
Table 3. Phytosociological parameters of families sampled in the restinga (shrublands) in Itaúnas, near the municipality of Conceição da Barra, in the state of Espírito Santo, Brazil.

\begin{tabular}{|c|c|c|c|c|c|c|c|c|c|c|}
\hline Family & S & $\mathrm{Ni}$ & $\mathrm{Ab}$ & $\mathrm{AF}$ & $\mathrm{AD}$ & ADo & RF & $\mathrm{RD}$ & RDo & IV \\
\hline Myrtaceae & 27 & 447 & 1.986 & 96 & 894 & 3.971 & 8.972 & 26.847 & 12.406 & 48.225 \\
\hline Burseraceae & 3 & 121 & 3.327 & 74 & 242 & 6.654 & 6.916 & 7.267 & 20.788 & 34.971 \\
\hline Lauraceae & 7 & 231 & 1.615 & 88 & 462 & 3.231 & 8.224 & 13.874 & 10.093 & 32.191 \\
\hline Sapotaceae & 8 & 148 & 1.179 & 90 & 296 & 2.358 & 8.411 & 8.889 & 7.366 & 24.666 \\
\hline Anacardiaceae & 3 & 43 & 2.000 & 44 & 86 & 3.999 & 4.112 & 2.583 & 12.494 & 19.189 \\
\hline Fabaceae & 10 & 75 & 1.206 & 66 & 150 & 2.411 & 6.168 & 4.505 & 7.533 & 18.206 \\
\hline Apocynaceae & 2 & 54 & 0.692 & 58 & 108 & 1.383 & 5.421 & 3.243 & 4.322 & 12.985 \\
\hline Annonaceae & 4 & 92 & 0.218 & 62 & 184 & 0.435 & 5.794 & 5.526 & 1.360 & 12.680 \\
\hline Humiriaceae & 1 & 53 & 0.541 & 56 & 106 & 1.082 & 5.234 & 3.183 & 3.379 & 11.796 \\
\hline Rutaceae & 5 & 82 & 0.116 & 36 & 164 & 0.232 & 3.364 & 4.925 & 0.725 & 9.014 \\
\hline Nyctaginaceae & 3 & 36 & 0.457 & 40 & 72 & 0.915 & 3.738 & 2.162 & 2.858 & 8.758 \\
\hline Calophyllaceae & 2 & 38 & 0.228 & 32 & 76 & 0.455 & 2.991 & 2.282 & 1.423 & 6.696 \\
\hline Chrysobalanaceae & 3 & 23 & 0.213 & 32 & 46 & 0.426 & 2.991 & 1.381 & 1.332 & 5.704 \\
\hline Sapindaceae & 2 & 16 & 0.274 & 28 & 32 & 0.549 & 2.617 & 0.961 & 1.715 & 5.293 \\
\hline Lecythidaceae & 1 & 21 & 0.224 & 26 & 42 & 0.448 & 2.430 & 1.261 & 1.399 & 5.090 \\
\hline Ochnaceae & 1 & 31 & 0.032 & 32 & 62 & 0.064 & 2.991 & 1.862 & 0.199 & 5.052 \\
\hline Peraceae & 3 & 22 & 0.137 & 20 & 44 & 0.273 & 1.869 & 1.321 & 0.853 & 4.044 \\
\hline Rubiaceae & 4 & 19 & 0.063 & 26 & 38 & 0.125 & 2.430 & 1.141 & 0.391 & 3.962 \\
\hline Clusiaceae & 2 & 6 & 0.388 & 10 & 12 & 0.776 & 0.935 & 0.360 & 2.424 & 3.719 \\
\hline Celastraceae & 2 & 12 & 0.066 & 22 & 24 & 0.132 & 2.056 & 0.721 & 0.412 & 3.188 \\
\hline Moraceae & 3 & 7 & 0.216 & 14 & 14 & 0.432 & 1.308 & 0.420 & 1.348 & 3.077 \\
\hline Meliaceae & 1 & 13 & 0.153 & 12 & 26 & 0.306 & 1.121 & 0.781 & 0.957 & 2.859 \\
\hline Malpighiaceae & 2 & 6 & 0.196 & 10 & 12 & 0.392 & 0.935 & 0.360 & 1.224 & 2.519 \\
\hline Olacaceae & 1 & 9 & 0.027 & 16 & 18 & 0.053 & 1.495 & 0.541 & 0.166 & 2.202 \\
\hline Bignoniaceae & 1 & 9 & 0.053 & 12 & 18 & 0.107 & 1.121 & 0.541 & 0.333 & 1.995 \\
\hline Malvaceae & 1 & 4 & 0.152 & 8 & 8 & 0.304 & 0.748 & 0.240 & 0.950 & 1.938 \\
\hline Salicaceae & 1 & 12 & 0.023 & 10 & 24 & 0.045 & 0.935 & 0.721 & 0.141 & 1.796 \\
\hline Simaroubaceae & 1 & 5 & 0.085 & 8 & 10 & 0.171 & 0.748 & 0.300 & 0.533 & 1.581 \\
\hline Melastomataceae & 1 & 9 & 0.010 & 6 & 18 & 0.020 & 0.561 & 0.541 & 0.063 & 1.164 \\
\hline Elaeocarpaceae & 1 & 5 & 0.014 & 8 & 10 & 0.028 & 0.748 & 0.300 & 0.087 & 1.135 \\
\hline Connaraceae & 1 & 5 & 0.005 & 8 & 10 & 0.011 & 0.748 & 0.300 & 0.033 & 1.081 \\
\hline Lamiaceae & 1 & 3 & 0.035 & 4 & 6 & 0.070 & 0.374 & 0.180 & 0.219 & 0.773 \\
\hline Icacinaceae & 1 & 2 & 0.036 & 4 & 4 & 0.072 & 0.374 & 0.120 & 0.225 & 0.719 \\
\hline Lacistemaceae & 1 & 2 & 0.022 & 4 & 4 & 0.045 & 0.374 & 0.120 & 0.141 & 0.634 \\
\hline Achariaceae & 1 & 1 & 0.009 & 2 & 2 & 0.019 & 0.187 & 0.060 & 0.058 & 0.305 \\
\hline Urticaceae & 1 & 1 & 0.003 & 2 & 2 & 0.007 & 0.187 & 0.060 & 0.021 & 0.268 \\
\hline Primulaceae & 1 & 1 & 0.003 & 2 & 2 & 0.006 & 0.187 & 0.060 & 0.020 & 0.267 \\
\hline Picramniaceae & 1 & 1 & 0.001 & 2 & 2 & 0.003 & 0.187 & 0.060 & 0.009 & 0.256 \\
\hline
\end{tabular}

$\mathrm{S}=$ number of species; $\mathrm{Ni}=$ number of individuals sampled; $\mathrm{Ba}=$ basal area; $\mathrm{AF}=$ absolute frequency; $\mathrm{AD}=$ absolute density; $\mathrm{ADo}=\mathrm{absolute}$ dominance; $\mathrm{RF}=$ relative frequency, $\mathrm{RD}=$ relative density, $\mathrm{RDo}=$ relative dominance, $\mathrm{IV}=$ importance value. 
Table 4. Parameters of the species sampled in the restinga (shrublands) in Itaúnas, near the municipality of Conceição da Barra, in the state of Espírito Santo, Brazil.

\begin{tabular}{|c|c|c|c|c|c|c|c|c|}
\hline Species & $\mathrm{Ni}$ & $\mathrm{AD}$ & $\mathrm{AF}$ & $\mathrm{ADo}$ & $\mathrm{RD}$ & $\mathrm{RF}$ & RDo & IV \\
\hline Protium heptaphyllum & 82 & 164 & 58 & 4.831 & 4.925 & 3.380 & 15.093 & 23.398 \\
\hline Ocotea lobbii & 148 & 296 & 80 & 1.861 & 8.889 & 4.662 & 5.813 & 19.364 \\
\hline Tapirira guianensis & 35 & 70 & 40 & 3.928 & 2.102 & 2.331 & 12.272 & 16.705 \\
\hline Eugenia astringens & 85 & 170 & 60 & 0.728 & 5.105 & 3.497 & 2.274 & 10.876 \\
\hline Eugenia excelsa & 77 & 154 & 56 & 0.662 & 4.625 & 3.263 & 2.068 & 9.956 \\
\hline Humiriastrum dentatum & 53 & 106 & 56 & 1.082 & 3.183 & 3.263 & 3.379 & 9.826 \\
\hline Macrolobium latifolium & 29 & 58 & 30 & 1.923 & 1.742 & 1.748 & 6.006 & 9.496 \\
\hline Unonopsis aurantiaca & 87 & 174 & 56 & 0.285 & 5.225 & 3.263 & 0.891 & 9.380 \\
\hline Pouteria caimito & 52 & 104 & 60 & 0.873 & 3.123 & 3.497 & 2.728 & 9.347 \\
\hline Myrcia vittoriana & 86 & 172 & 44 & 0.311 & 5.165 & 2.564 & 0.970 & 8.699 \\
\hline Himatanthus phagedaenicus & 42 & 84 & 48 & 1.031 & 2.523 & 2.797 & 3.222 & 8.542 \\
\hline Protium icicariba & 30 & 60 & 22 & 1.328 & 1.802 & 1.282 & 4.148 & 7.232 \\
\hline Eugenia bahiensis & 36 & 72 & 44 & 0.586 & 2.162 & 2.564 & 1.832 & 6.558 \\
\hline Ocotea glaziovii & 27 & 54 & 30 & 0.800 & 1.622 & 1.748 & 2.498 & 5.868 \\
\hline Micropholis venulosa & 21 & 42 & 24 & 0.871 & 1.261 & 1.399 & 2.721 & 5.380 \\
\hline Guapira obtusata & 20 & 40 & 28 & 0.776 & 1.201 & 1.632 & 2.425 & 5.258 \\
\hline Marlierea regeliana & 28 & 56 & 34 & 0.258 & 1.682 & 1.981 & 0.805 & 4.468 \\
\hline Rauia cf. nodosa & 43 & 86 & 24 & 0.112 & 2.583 & 1.399 & 0.351 & 4.332 \\
\hline Eschweilera ovata & 21 & 42 & 26 & 0.448 & 1.261 & 1.515 & 1.399 & 4.176 \\
\hline Ouratea cuspidata & 31 & 62 & 32 & 0.064 & 1.862 & 1.865 & 0.199 & 3.926 \\
\hline Esenbeckia grandiflora & 36 & 72 & 24 & 0.116 & 2.162 & 1.399 & 0.363 & 3.923 \\
\hline Marlierea sucrei & 17 & 34 & 26 & 0.425 & 1.021 & 1.515 & 1.329 & 3.865 \\
\hline Kielmeyera albopunctata & 22 & 44 & 22 & 0.251 & 1.321 & 1.282 & 0.785 & 3.388 \\
\hline Ocotea notata & 21 & 42 & 24 & 0.220 & 1.261 & 1.399 & 0.687 & 3.347 \\
\hline Pouteria coelomatica & 18 & 36 & 24 & 0.197 & 1.081 & 1.399 & 0.617 & 3.096 \\
\hline Pouteria grandiflora & 19 & 38 & 26 & 0.137 & 1.141 & 1.515 & 0.429 & 3.085 \\
\hline Cupania emarginata & 8 & 16 & 16 & 0.483 & 0.480 & 0.932 & 1.508 & 2.921 \\
\hline Trattinnickia mensalis & 9 & 18 & 12 & 0.495 & 0.541 & 0.699 & 1.547 & 2.787 \\
\hline Aspidosperma pyricollum & 12 & 24 & 16 & 0.352 & 0.721 & 0.932 & 1.100 & 2.753 \\
\hline Myrcia ilheosensis & 18 & 36 & 24 & 0.080 & 1.081 & 1.399 & 0.250 & 2.730 \\
\hline Guapira opposita & 14 & 28 & 24 & 0.136 & 0.841 & 1.399 & 0.425 & 2.664 \\
\hline Manilkara subsericea & 18 & 36 & 20 & 0.115 & 1.081 & 1.166 & 0.359 & 2.605 \\
\hline Campomanesia guazumifolia & 15 & 30 & 16 & 0.246 & 0.901 & 0.932 & 0.768 & 2.602 \\
\hline Guarea penningtoniana & 13 & 26 & 12 & 0.306 & 0.781 & 0.699 & 0.957 & 2.437 \\
\hline Ocotea sp.1 & 16 & 32 & 18 & 0.134 & 0.961 & 1.049 & 0.418 & 2.428 \\
\hline Kielmeyera membranacea & 16 & 32 & 14 & 0.204 & 0.961 & 0.816 & 0.638 & 2.415 \\
\hline Couepia schottii & 8 & 16 & 14 & 0.318 & 0.480 & 0.816 & 0.995 & 2.291 \\
\hline Maytenus distichophylla & 11 & 22 & 20 & 0.130 & 0.661 & 1.166 & 0.407 & 2.233 \\
\hline Aniba firmula & 12 & 24 & 18 & 0.127 & 0.721 & 1.049 & 0.396 & 2.166 \\
\hline Abarema filamentosa & 14 & 28 & 10 & 0.214 & 0.841 & 0.583 & 0.667 & 2.091 \\
\hline Pouteria peduncularis & 13 & 26 & 18 & 0.047 & 0.781 & 1.049 & 0.148 & 1.978 \\
\hline
\end{tabular}


Table 4. Continuation.

\begin{tabular}{|c|c|c|c|c|c|c|c|c|}
\hline Species & $\mathrm{Ni}$ & $\mathrm{AD}$ & $\mathrm{AF}$ & ADo & $\mathrm{RD}$ & $\mathrm{RF}$ & $\mathrm{RDo}$ & IV \\
\hline Byrsonima sericea & 5 & 10 & 8 & 0.375 & 0.300 & 0.466 & 1.170 & 1.937 \\
\hline Eugenia dichroma & 9 & 18 & 16 & 0.145 & 0.541 & 0.932 & 0.452 & 1.925 \\
\hline Garcinia brasiliensis & 4 & 8 & 8 & 0.351 & 0.240 & 0.466 & 1.095 & 1.802 \\
\hline Plinia grandifolia & 10 & 20 & 18 & 0.048 & 0.601 & 1.049 & 0.150 & 1.800 \\
\hline Simira glaziovii & 11 & 22 & 14 & 0.102 & 0.661 & 0.816 & 0.318 & 1.795 \\
\hline Pera glabrata & 12 & 24 & 8 & 0.184 & 0.721 & 0.466 & 0.575 & 1.762 \\
\hline Clusia hilariana & 2 & 4 & 4 & 0.425 & 0.120 & 0.233 & 1.329 & 1.682 \\
\hline Eriotheca macrophylla & 4 & 8 & 8 & 0.304 & 0.240 & 0.466 & 0.950 & 1.657 \\
\hline Heisteria perianthomega & 9 & 18 & 16 & 0.053 & 0.541 & 0.932 & 0.166 & 1.639 \\
\hline Tabebuia roseoalba & 9 & 18 & 12 & 0.107 & 0.541 & 0.699 & 0.333 & 1.573 \\
\hline Eugenia sulcata & 10 & 20 & 14 & 0.034 & 0.601 & 0.816 & 0.105 & 1.522 \\
\hline Cupania racemosa & 8 & 16 & 14 & 0.066 & 0.480 & 0.816 & 0.206 & 1.503 \\
\hline Casearia commersoniana & 12 & 24 & 10 & 0.045 & 0.721 & 0.583 & 0.141 & 1.444 \\
\hline Swartzia apetala & 9 & 18 & 14 & 0.022 & 0.541 & 0.816 & 0.068 & 1.424 \\
\hline Eugenia sp.1 & 10 & 20 & 12 & 0.040 & 0.601 & 0.699 & 0.124 & 1.424 \\
\hline Myrcia splendens & 8 & 16 & 14 & 0.038 & 0.480 & 0.816 & 0.119 & 1.415 \\
\hline Couepia sp. & 10 & 20 & 10 & 0.071 & 0.601 & 0.583 & 0.223 & 1.406 \\
\hline Pera leandri & 7 & 14 & 12 & 0.067 & 0.420 & 0.699 & 0.209 & 1.329 \\
\hline Simaruba amara & 5 & 10 & 8 & 0.171 & 0.300 & 0.466 & 0.533 & 1.300 \\
\hline Aiouea saligna & 6 & 12 & 10 & 0.084 & 0.360 & 0.583 & 0.262 & 1.205 \\
\hline Ficus cf. trigona & 4 & 8 & 8 & 0.149 & 0.240 & 0.466 & 0.466 & 1.173 \\
\hline Spondias macrocarpa & 7 & 14 & 10 & 0.050 & 0.420 & 0.583 & 0.157 & 1.160 \\
\hline Pterocarpus rohrii & 5 & 10 & 10 & 0.058 & 0.300 & 0.583 & 0.181 & 1.064 \\
\hline Licania heteromorpha & 5 & 10 & 10 & 0.037 & 0.300 & 0.583 & 0.115 & 0.998 \\
\hline Ficus gomelleira & 1 & 2 & 2 & 0.259 & 0.060 & 0.117 & 0.808 & 0.985 \\
\hline Neomitranthes langsdorffii & 4 & 8 & 6 & 0.122 & 0.240 & 0.350 & 0.382 & 0.972 \\
\hline Sloanea guianensis & 5 & 10 & 10 & 0.028 & 0.300 & 0.583 & 0.087 & 0.970 \\
\hline Miconia cf. pusilliflora & 9 & 18 & 6 & 0.020 & 0.541 & 0.350 & 0.063 & 0.953 \\
\hline Neomitranthes obtusa & 4 & 8 & 8 & 0.074 & 0.240 & 0.466 & 0.232 & 0.939 \\
\hline Andira fraxinifolia & 6 & 12 & 8 & 0.035 & 0.360 & 0.466 & 0.108 & 0.935 \\
\hline Pouteria aff. psammophila & 4 & 8 & 8 & 0.060 & 0.240 & 0.466 & 0.189 & 0.895 \\
\hline Inga subnuda & 4 & 8 & 6 & 0.091 & 0.240 & 0.350 & 0.286 & 0.876 \\
\hline Myrciaria floribunda & 4 & 8 & 8 & 0.038 & 0.240 & 0.466 & 0.118 & 0.824 \\
\hline Amaioua intermedia & 5 & 10 & 8 & 0.018 & 0.300 & 0.466 & 0.057 & 0.824 \\
\hline Annona salzmannii & 2 & 4 & 4 & 0.145 & 0.120 & 0.233 & 0.453 & 0.807 \\
\hline Connarus blanchetii & 5 & 10 & 8 & 0.011 & 0.300 & 0.466 & 0.033 & 0.799 \\
\hline Zollernia glabra & 4 & 8 & 8 & 0.015 & 0.240 & 0.466 & 0.046 & 0.752 \\
\hline Eugenia pisiformis & 5 & 10 & 6 & 0.023 & 0.300 & 0.350 & 0.071 & 0.721 \\
\hline Eugenia brasiliensis & 5 & 10 & 6 & 0.013 & 0.300 & 0.350 & 0.042 & 0.692 \\
\hline Vitex polygama & 3 & 6 & 4 & 0.070 & 0.180 & 0.233 & 0.219 & 0.633 \\
\hline Chrysophyllum splendens & 3 & 6 & 4 & 0.056 & 0.180 & 0.233 & 0.176 & 0.589 \\
\hline
\end{tabular}


Table 4. Continuation

\begin{tabular}{|c|c|c|c|c|c|c|c|c|}
\hline Species & $\mathrm{Ni}$ & $\mathrm{AD}$ & $\mathrm{AF}$ & ADo & $\mathrm{RD}$ & $\mathrm{RF}$ & RDo & IV \\
\hline Emmotum nitens & 2 & 4 & 4 & 0.072 & 0.120 & 0.233 & 0.225 & 0.579 \\
\hline Myrciaria tenella & 3 & 6 & 6 & 0.004 & 0.180 & 0.350 & 0.013 & 0.543 \\
\hline Lacistema robustum & 2 & 4 & 4 & 0.045 & 0.120 & 0.233 & 0.141 & 0.494 \\
\hline Matayba guianensis & 2 & 4 & 4 & 0.039 & 0.120 & 0.233 & 0.122 & 0.475 \\
\hline Eugenia sp.2 & 3 & 6 & 4 & 0.016 & 0.180 & 0.233 & 0.048 & 0.462 \\
\hline Inga exfoliata & 2 & 4 & 4 & 0.025 & 0.120 & 0.233 & 0.080 & 0.433 \\
\hline Ficus cf. bahiensis & 2 & 4 & 4 & 0.024 & 0.120 & 0.233 & 0.074 & 0.427 \\
\hline Melanopsidium nigrum & 2 & 4 & 4 & 0.004 & 0.120 & 0.233 & 0.012 & 0.366 \\
\hline Pogonophora schomburgkiana & 3 & 6 & 2 & 0.022 & 0.180 & 0.117 & 0.068 & 0.365 \\
\hline Psidium brownianum & 2 & 4 & 4 & 0.004 & 0.120 & 0.233 & 0.012 & 0.365 \\
\hline Xylopia sericea & 2 & 4 & 4 & 0.004 & 0.120 & 0.233 & 0.012 & 0.365 \\
\hline Guapira sp. & 2 & 4 & 4 & 0.003 & 0.120 & 0.233 & 0.008 & 0.361 \\
\hline Myrcia cerqueiria & 2 & 4 & 2 & 0.019 & 0.120 & 0.117 & 0.059 & 0.296 \\
\hline Andira nitida & 1 & 2 & 2 & 0.025 & 0.060 & 0.117 & 0.078 & 0.254 \\
\hline Schinus terebinthifolius & 1 & 2 & 2 & 0.021 & 0.060 & 0.117 & 0.065 & 0.242 \\
\hline Carpotroche brasiliensis & 1 & 2 & 2 & 0.019 & 0.060 & 0.117 & 0.058 & 0.234 \\
\hline Byrsonima bahiana & 1 & 2 & 2 & 0.017 & 0.060 & 0.117 & 0.053 & 0.230 \\
\hline Eugenia brejoensis & 1 & 2 & 2 & 0.010 & 0.060 & 0.117 & 0.031 & 0.207 \\
\hline Cecropia pachystachya & 1 & 2 & 2 & 0.007 & 0.060 & 0.117 & 0.021 & 0.198 \\
\hline Myrsine guianensis & 1 & 2 & 2 & 0.006 & 0.060 & 0.117 & 0.020 & 0.196 \\
\hline Myrcia bergiana & 1 & 2 & 2 & 0.006 & 0.060 & 0.117 & 0.019 & 0.196 \\
\hline Ocotea sp.2 & 1 & 2 & 2 & 0.006 & 0.060 & 0.117 & 0.018 & 0.195 \\
\hline Swartzia simplex & 1 & 2 & 2 & 0.005 & 0.060 & 0.117 & 0.014 & 0.191 \\
\hline Picramnia gardneri & 1 & 2 & 2 & 0.003 & 0.060 & 0.117 & 0.009 & 0.186 \\
\hline Eugenia inversa & 1 & 2 & 2 & 0.003 & 0.060 & 0.117 & 0.008 & 0.185 \\
\hline Maytenus cf. communis & 1 & 2 & 2 & 0.002 & 0.060 & 0.117 & 0.005 & 0.182 \\
\hline Conchocarpus longifolius & 1 & 2 & 2 & 0.001 & 0.060 & 0.117 & 0.004 & 0.181 \\
\hline Pilocarpus grandiflora & 1 & 2 & 2 & 0.001 & 0.060 & 0.117 & 0.004 & 0.181 \\
\hline Conchocarpus insignis & 1 & 2 & 2 & 0.001 & 0.060 & 0.117 & 0.004 & 0.180 \\
\hline Duguetia sessilis & 1 & 2 & 2 & 0.001 & 0.060 & 0.117 & 0.003 & 0.180 \\
\hline Psychotria carthagenensis & 1 & 2 & 2 & 0.001 & 0.060 & 0.117 & 0.003 & 0.180 \\
\hline Calyptranthes brasiliensis & 1 & 2 & 2 & 0.001 & 0.060 & 0.117 & 0.003 & 0.180 \\
\hline
\end{tabular}

$\mathrm{Ni}=$ number of individuals sampled; $\mathrm{AF}=$ absolute frequency; $\mathrm{AD}=$ absolute density; $\mathrm{ADo}=$ absolute dominance; $\mathrm{RF}=$ relative frequency, $\mathrm{RD}=$ relative density, $\mathrm{RDo}=$ relative dominance, $\mathrm{IV}=$ importance value .

region. The pattern observed allows us to conclude that the environmental conditions of the areas evaluated, including climatic conditions generated by latitude, proximity to other vegetation types and the influence of human activity, might explain the similarities and differences found for this family along the coast (Guedes et al. 2006).

Although there was considerable density of Annonaceae species, mainly U. aurantiaca, in the lower and middle strata, the great numbers of Myrtaceae species in these strata made the latter family predominant. However, in the upper strata, Myrtaceae species become less representative for all parameters, confirming that it is a family typical of the lower strata, as stated by Tabarelli \& Mantovani (1997). The middle stratum is representative of species in development, which are also present in the upper strata, thus contributing to the maintenance of species diversity in this forest. However, individuals in the upper stratum contribute little to the richness and density, although they are primarily responsible 
Chart 1. Selection of shrub/tree species of the coastal forests of the state of Espírito Santo (ES), Brazil, based on the classification of 14 areas by two-way indicator species analysis.

\begin{abstract}
Preferentials of restingas in northern ES: Abarema filamentosa, Acosmium bijugum, Chrysophyllum splendens, Clavija spinosa, Couepia schottii, Eriotheca macrophylla, Eugenia brasiliensis, Ficus gomelleira, Humiriastrum dentatum, Joannesia princeps, Lacistema robustum, Macrolobium latifolium, Picramnia gardneri, Piptadenia adiantoides, Pogonophora schomburgkiana, Protium icicariba, Pterocarpus rohrii, Simarouba amara, Tabebuia roseoalba.

Preferentials of restingas in southern ES: Abarema jupumba, Annona acutifolia, Buchenavia tetraphylla, Cathedra rubricaulis, Coussapoa microcarpa, Crataeva tapia, Daphnopsis coriacea, Dulacia singularis, Eriotheca pentaphylla, Eugenia speciosa, Exostyles venusta, Ficus hirsuta, Hymenaea rubriflora, Marlierea glabra, Myrcia racemosa, Pseudobombax grandiflorum, Trichilia pallens, T. pseudostipularis.

Broad distribution in the restingas of ES: Anacardium occidentale, Byrsonima sericea, Andira fraxinifolia, A. nitida, Aspidosperma pyricollum, Bactris vulgaris, Calyptranthes brasiliensis, Capparis flexuosa, Chamaecrista ensiformis, Chiococca alba, Clusia hilariana, C. spiritu-sanctensis, Coccoloba alnifolia, Cupania emarginata, Eschweilera ovata, Erythroxylum subsessile, Esenbeckia grandiflora, E. astringens, Eugenia excelsa, E. punicifolia, E. sulcata, Garcinia brasiliensis, Guapira opposita, Guarea guidonia, Heisteria perianthomega, Himatanthus phagedaenicus, Inga subnuda, Jacaranda puberula, Kielmeyera albopunctata, Manilkara subsericea, Matayba guianensis, Maytenus obtusifolia, Melanoxylum nigrum, Micropholis venulosa, Mollinedia glabra, Myrcia bergiana, M. splendens, M. vittoriana, Myrciaria floribunda, Ocotea lobbii, O. notata, Opuntia brasiliensis, Ouratea cuspidata, Pera glabrata, P. leandri, Piper arboreum, Pouteria caimito, P. coelomatica, Protium heptaphyllum, Psidium brownianum, P. cattleianum, Rhodostemonodaphne capixabensis, Schinus terebinthifolius, Stigmaphyllon paralis, Simaba cuneata, Sorocea hilarii, Swartzia apetala, Xylopia sericea, X. laevigata, Ziziphus platiphylla, Zollernia glabra.

Preferentials of the tabuleiro forests of northern ES: Allophylus petiolutatus, Andira ormosioides, Annona cacans, Aspidosperma ilustre, Astronium concinmum, A. graveolens, Banara brasiliensis, Blepharocalyx eggersii, Bombacopsis stenopetala, Brosimum guianense, Buchenavia rabelloana, Calyptranthes lucida, Campomanesia espiritosantensis, Carpotroche brasiliensis, Caryocar edule, Caryodendron grandifolium, Casearia commersoniana, C. decandra, Cecropia glaziovi, Cedrela odorata, Chrysophyllum lucentifolium, C. splendens, Citronella paniculata, Clarisia racemosa, Cordia sellowiana, Couepia carautae, Couratari asterotricha, Cupania rugosa, Deguelia longeracemosa, Dialium guianensis, Diplotropis incexis, Ecclinusa ramiflora, Eriotheca macrophylla, Eugenia pisiformis, E. pruinosa, E. ternatifolia, Exellodendron gracile, Faramea bahiensis, Garcinia gardneriana, Geissospermum laeve, Guarea penningtoniana, Guettarda angelica, Helicostylis tomentosa, Hidrogaster trinervis, Hirtella hebeclada, Inga flagelliformis, I. hispida, Jacaratia heptaphylla, Joannesia princeps, Lacistema recurvum, Lecythis lanceolata, L. lurida, Licania kunthiana, L. octandra, L. salzmanii, Luehea mediterranea, Machaerium fulvovenosum, M. ovalifolium, Manilkara bella, M. salzmannii, Margaritaria nobilis, Marlierea estrellensis, M. sucrei, Melanoxylon brauna, Micropholis crassipedicelata, M. cuneata, Mollinedia marquetiana, Myrcia lineata, M. multiflora, Myrocarpus fastigianus, Neoraputia alba, Ocotea argentea, O. conferta, O. confertiflora, O. elegans, O. odorifera, O. velutina, Ormosia nitida, Parapiptadenia pterosperma, Piptadenia paniculata, Plinia involucrata, Polyandrococos caudescens, Pouteria bangii, P. cuspidata, Pradosia lactescens, Protium warmingianum, Pseudopiptadenia contorta, Psychotria carthagenensis, Quararibea penduliflora, Randia armata, Rinorea bahiensis, Schefflera morototoni, Schoepfia oblongifolia, Sclerolobium striatum, Senefeldera multiflora, Simarouba amara, Simira glaziovii, S. grazielae, Siparuna reginae, Sorocea guilleminiana, Spondias venulosa, Stephanopodium blanchetianum, Sterculia speciosa, Swartzia simplex, Sweetia fruticosa, Tabebuia obtusifolia, T. roseoalba, Thyrsodium schomburgkianum, Vatairea heteroptera, Virola gardneri.
\end{abstract}

Restinga - shrublands; tabuleiro forests - coastal lowland forests on Tertiary

for biomass stocks, given their high representation in terms of basal area. Because the low nutrient content in the soil of the restinga makes biomass the principal nutritional reserve maintained through nutrient cycling (Guedes et al. 2006), the upper and lower strata are both quite important for maintaining the structural complexity of this type of forest.

For the species-area curve, our sampling can be considered sufficient despite the high proportion of species represented by only one individual. In restingas, this does not necessarily indicate that the species are rare. For example, in a restinga in southern Espírito Santo, Schinus terebinthifolius was found to be represented by a single individual (Assis et al. 2004b). In shrub formations along the backshore, as well as in disturbed environments, S. terebinthifolius has a higher density (Assumpção \& Nascimento 2000; Lobão \& Kurtz 2000; Menezes \& Araujo 2005). In previous studies, the number of shrub and tree species observed in restinga vegetation formations has varied considerably, species richness typically being highest in terra firme forest, although rarely exceeding 150 species (Pereira 1990, Pereira \& Araujo 2000; Silva \& Britz 2005; Menezes \& Araujo 2005; Amaral et al. 2008). In the present study, we observed a high number of species with low density, in comparison with other restingas of Brazil, which might be an intrinsic characteristic of the community evaluated and could be responsible for the increase in species diversity.

In the Itaúnas restinga, the diversity index, density and basal area were higher than in other Brazilian restingas (Assumpção \& Nascimento 2000; Waechter et al. 2000; Scherer et al. 2005; Guedes et al. 2006; Sá \& Araujo 2009), which could be indicative of a good state of preservation. In addition to the higher diversity index, Myrtaceae richness and overall species richness were higher in our sample than in those of other studies of the vegetation of restingas in Espírito Santo (Fabris \& César 1996; Assis et al. 2004b). However, this result might have been influenced by the fact that our inclusion criteria were broader than were those of some of the aforementioned studies, resulting in a more inclusive sample. By adopting a DBH $\geq 5 \mathrm{~cm}$ as an inclusion criteria, we eliminated 16 species (three Myrtaceae) and 850 individuals $(51 \%$ of the total) from our sample, the final sample therefore totaling 98 species. Nevertheless, the values of H' and J' (3.93 and 0.856, respectively) were still higher than those obtained for other restingas in Espírito 


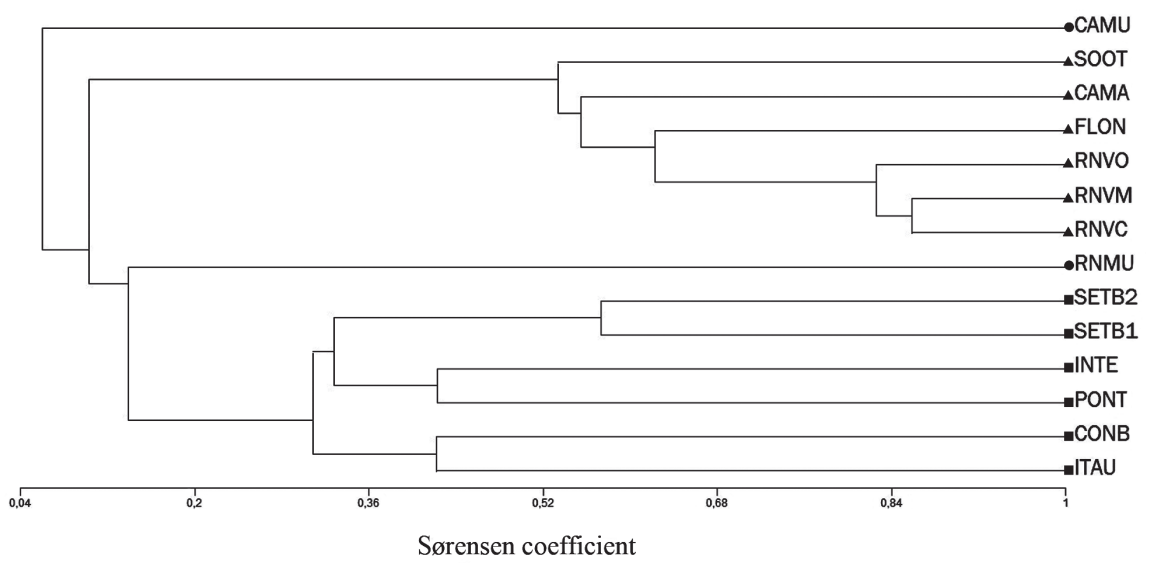

Figure 4. Dendrogram of similarity (unweighted pair group method with arithmetic mean), using the Sørensen coefficient, generated through qualitative data related to 14 coastal forests in the state of Espírito Santo and in the southern part of the state of Bahia, Brazil.

$\boldsymbol{-}=$ restinga,$\bullet=$ muçununga $; \mathbf{\Lambda}=$ mata alta (tall forest).

Restinga - shrublands; muçununga - similar to restinga but established on Tertiary land, forming enclaves in the mata alta (tall forest); CAMU - muçununga in the municipality of Caravelas (state of Bahia); SOOT - Sooretama Biological Reserve (state of Espírito Santo-ES); CAMA - mata alta in Caravelas; FLON - Rio Preto National Forest; RNVO - Oiticica Natural Vale Reserve; RNVM - Macanaíba Natural Vale Reserve; RNVC - Caigá Natural Vale Reserve; RNMU - muçununga in Natural Vale Reserve; SETB2 - 2nd location within Setiba Park (now Paulo César Vinha State Park); SETB1 - 1st location within Setiba Park; INTE - Interlagos; PONT - Pontal do Ipiranga; CONB - Conceição da Barra; ITAU - Itaúnas.

Santo and for those in other Brazilian states. Therefore, the exclusion of individuals with a $\mathrm{DBH}<5 \mathrm{~cm}$ implied partial exclusion of the undergrowth, interfering little in the total number of species, given that the middle stratum comprises the largest portion of the wealth of this forest.

Tree death is a natural process triggered by biotic or abiotic conditions that contribute to the forest dynamics of tropical ecosystems (Franklin et al. 1987). In the Itaúnas restinga, dead trees, if they were to be considered in a specific category, would rank 4 th in IV, with a density of 214 ind./ ha. This value is higher than that found for restingas with well-drained soils along the coast-such as the 58.9 ind./ha reported for the Tavares restinga, in the state of Rio Grande do Sul (Dorneles \& Waechter 2004); the 67.0 ind./ha and 104.0 ind./ha reported for the restingas in Paulo César Vinha State Park, in Espírito Santo (Assis et al. 2004b; Fabris 1995); and the 120.0 ind./ha reported for the Armação de Buzios restinga, in the state of Rio de Janeiro (Lobão \& Kurtz 2000) - as well as that found for poorly drained restingas, such as the $152.0 \mathrm{ind}$./ha reported for the Marambaia restinga, in the state of Rio de Janeiro (Menezes et al. 2010). However, the basal area of dead trees in Itaúnas was similar to that found for those well-drained restingas and lower than that found for the poorly drained Marambaia restinga $\left(1.28 \mathrm{~m}^{2} / \mathrm{ha}\right)$. This can be attributed to the fact that flooding creates soil conditions that restrict tree development (Menezes et al. 2010). In addition, the significant difference between our findings and those of other studies of restingas, in terms of the density of dead trees, can be attributed to the inclusion criterion adopted in our study $(\mathrm{DBH} \geq 2.5$, a diameter smaller than that used in other studies). This allowed for the inclusion of a high density of thin individuals, as evidenced by the concentration of individuals in the first two diameter classes, which are more susceptible to disease, climate change and senescence due to competition for light (Franklin et al. 1987).

The concentration of the IV in a few species is common in Brazilian restingas. In the present study, this became apparent when we summed the IVs of the 13 most important species, which were found to account for approximately $50 \%$ of the total density of IV and approximately $60 \%$ of the total dominance, as reported for other restingas along the coast (Assumpção \& Nascimento 2000; Assis et al. 2004b). This indicates that environmental factors regulate the composition of species, limiting their establishment and development, resulting in a highly oligarchic structure that can reflect severe environmental conditions, such as the highly porous and nutrient-poor nature of the restinga soil, which is unfavorable for the establishment of many species (Scarano 2002). However, some species seem to flourish in these environmental conditions, particularly those belonging to the family Myrtaceae, which stood out in this forest due to their high density, which is common in restingas. Trindade (1991), studying a shrub/tree restinga near the city of Natal, noted the predominance of Myrtaceae in the sample, attributing this to some power over other species or to a better ability to take advantage of available resources.

The low similarity coefficients found for the coastal forests of Espírito Santo showed high floristic diversity, given that similarity coefficients greater than or equal to 0.5 indicate high floristic similarity (Kent \& Coker 1992). These conclusions must be interpreted with caution, because this floristic heterogeneity might, in part, reflect differences among the sampling methods employed for the various areas evaluated. Nevertheless, this does not invalidate the results showing that, despite their proximity to each other, 


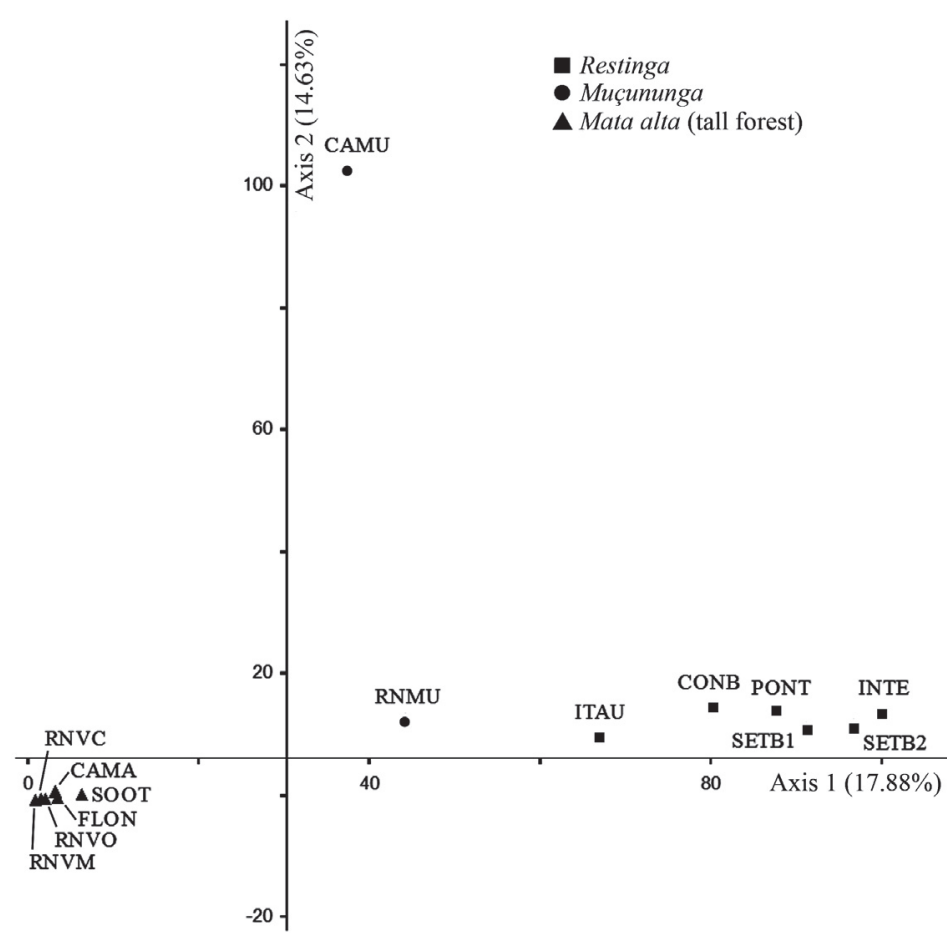

Figure 5. Ordination diagram by correspondence analysis for qualitative data related to 14 coastal forests in the state of Espírito Santo and in the southern part of the state of Bahia, Brazil.

Restinga - shrublands; muçununga - similar to restinga but established on Tertiary land, forming enclaves in the mata alta (tall forest); CAMA - mata alta in Caravelas; FLON - Rio Preto National Forest; RNVO - Oiticica Natural Vale Reserve; RNVM - Macanaíba Natural Vale Reserve; RNVC - Caigá Natural Vale Reserve; RNMU - muçununga in Natural Vale Reserve; SETB2 - 2nd location within Setiba Park (now Paulo César Vinha State Park); SETB1 - 1st location within Setiba Park; INTE - Interlagos; PONT - Pontal do Ipiranga; CONB - Conceição da Barra; ITAU - Itaúnas.

these forests show floristic characteristics that are particular to each region, a pattern commonly found in Brazilian restingas (Pereira 1990; Assis et al. 2004a; Scherer et al. 2005; Amaral et al. 2008). This high floristic heterogeneity complicates the implementation of environmental restoration programs, because of uncertainties over which species to be used, given that the introduction of an exotic species can harm the ecological system (Lani et al. 2008). Therefore, the identification of preferentially occurring species in this region is aimed at facilitating this process.

According to the TWINSPAN, C. flexuosa, G. brasiliensis and $P$. heptaphyllum were identified as preferential to restinga and as characteristic of the restinga of Espírito Santo, in relation to its tabuleiro forests, the latter making an important contribution to the structure of the restinga tree community (Assis et al. 2004b). In the TWINSPAN division, we found G. opposita to be non-preferential, which is in agreement with studies indicating that it is a generalist species (Oliveira-Filho \& Fontes 2000).

The similarity dendrogram shows that the restingas of Espírito Santo do not form clusters clearly distinguishing those in the north of the state from those in the south. For example, the Pontal do Ipiranga restinga, along the northern coast, showed greatest floristic similarity to the Interlagos restinga, located on the southern coast. However, this finding should also be interpreted with caution, because, despite sharing characteristics with the southern restinga cluster, the Pontal do Ipiranga restinga has few species in common with those forests, which precludes any hierarchical divisions in the TWINSPAN. Therefore, the inclusion of the Pontal do Ipiranga restinga weakens the structure of that cluster, because it is an artifact of the analysis, probably attributable to differences in methodology and sampling power among the studies.

The low floristic similarity between the Itaúnas and Conceição da Barra restingas denotes an intrinsic character of the restingas, reflecting the high heterogeneity among the sites surveyed, in terms of species composition. This uniqueness provides evidence that the tabuleiro forest, given its proximity, had an influence on the Itaúnas restinga, providing seedlings of uncommon species that find conditions favorable to their establishment in the restingas. Other species identified by the TWINSPAN as preferential to the tabuleiro forests of northern Espírito Santo can also be found in the Itaúnas restinga, including Eugenia pisiformis, Jacaratia heptaphylla, Marlierea sucrei, Swartzia simplex and Tabebuia roseoalba (Chart 1).

Although the muçununga forest in Linhares (Natural Vale Reserve) was established on Tertiary land, forming enclaves in the mata alta, it features soil conditions similar to those observed in the restingas analyzed, the soil being essentially sandy and well-drained (Simonelli et al. 2008), which justifies its position in the dendrogram. The muçununga forest in Caravelas is flooded periodically (Meira- 
-Neto et al. 2005), which explains the low degree of floristic similarity between this and the other formations. Chief among the species identified by the TWINSPAN as preferential is Tabebuia cassinoides (Lam.) DC., which is known to tolerate poorly drained environments (Scarano 2002).

The northern Espírito Santo/southern Bahia region is a recognized focus of plant species diversity (Peixoto \& Silva 1997), presenting a unique biogeographic pattern in that it constitutes an area within which semideciduous lowland forests and northern rainforests overlap, which could generate floristic affinities even between geographically distant areas, given the strong floristic links with tabuleiro forests in that region (Oliveira-Filho \& Fontes 2000; Rolim et al. 2006). Some of the species identified by the TWINSPAN as responsible for the clustering have also been cited for Atlantic Forest, in the northern lowlands of Espírito Santo (Oliveira-Filho \& Fontes 2000), including Brosimum guianense, Carpotroche brasiliensis, Caryocar edule, Cedrela odorata, J. princeps, Melanoxylon brauna, T. roseoalba and Virola gardneri, as well as in the lowlands to the south, including Allophylus petiolulatus, Ecclinusa ramiflora, Micropholis crassipedicellata, Pouteria venosa, Psychotria carthagenensis and Sweetia fruticosa.

In the correspondence analysis, we obtained eigenvalues that are considered high and therefore indicative of good separation of areas, as well as indicating complete turnover of species along its axes (ter Braak 1995). According to the ordination diagram, the restingas formed an ordered cluster that was essentially aligned toward a gradient of floristic similarities, graphically illustrating the possibility that the distance between the restingas of Espírito Santo and the tabuleiro forests (in the north of Espírito Santo and the south of Bahia) creates gradual variations in species composition, in which the Itaúnas restinga was notable for its degree of similarity with the tabuleiro forests. In addition,

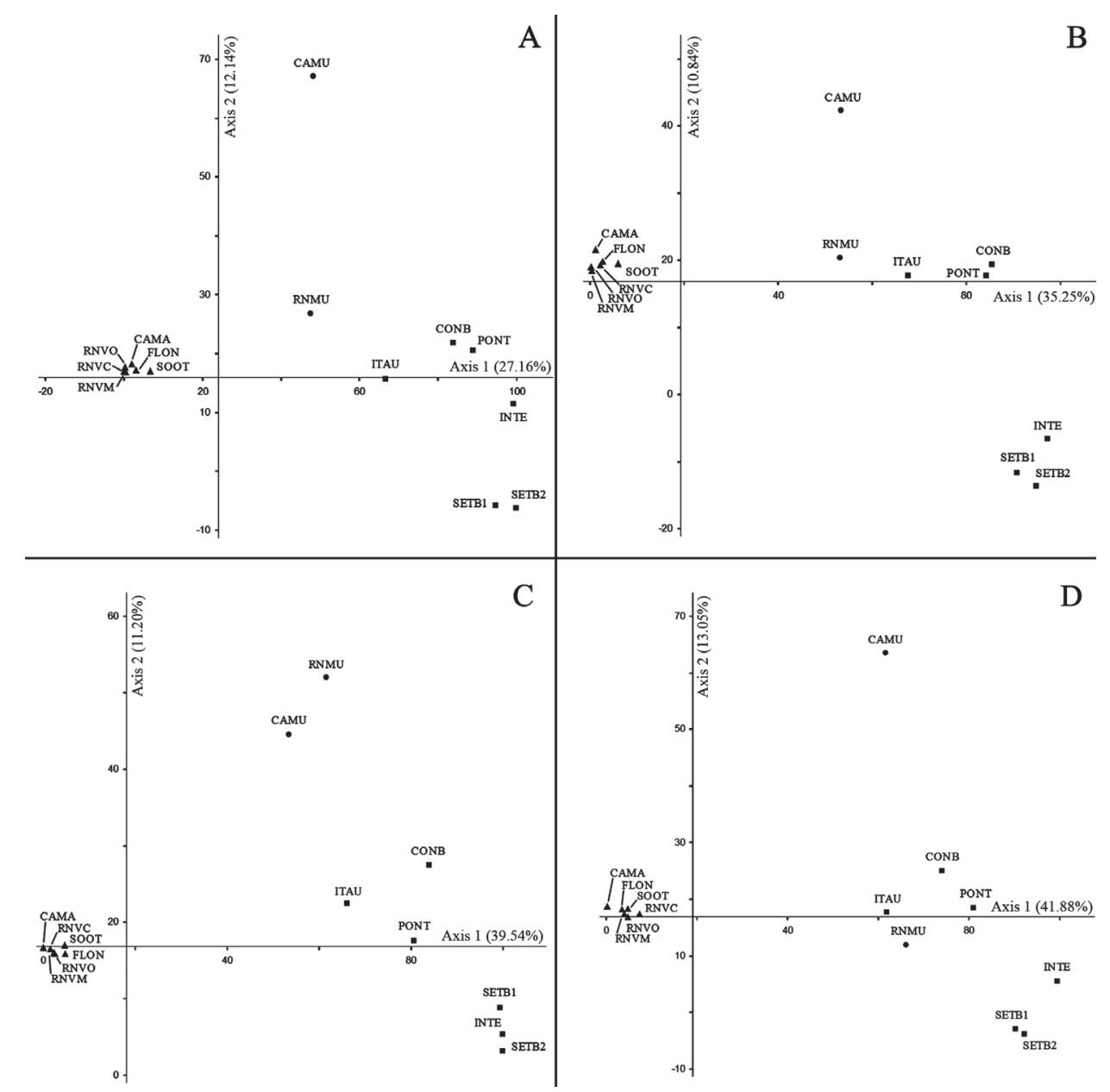

Figure 6. Ordination diagrams generated by correspondence analysis for qualitative data from 14 coastal forests in the state of Espírito Santo and in the southern part of the state of Bahia, Brazil, resulting from the exclusion of species occurring in only one area (A); in only two areas (B); in only three areas (C); and in only four areas (D).

- = restinga,$\bullet=$ muçununga; $\boldsymbol{\Delta}=$ mata alta (tall forest).

Restinga - shrublands; muçununga - similar to restinga but established on Tertiary land, forming enclaves in mata alta (tall forest); CAMA - mata alta in Caravelas; FLON - Rio Preto National Forest; RNVO - Oiticica Natural Vale Reserve; RNVM - Macanaíba Natural Vale Reserve; RNVC - Caigá Natural Vale Reserve; RNMU - Natural Vale Reserve; SETB2 - 2nd location within Setiba Park (now Paulo César Vinha State Park); SETB1 - 1st location within Setiba Park; INTE - Interlagos; PONT - Pontal do Ipiranga; CONB - Conceição da Barra; ITAU - Itaúnas. 
the difference between the Itaúnas restinga and the southern restingas, in terms of floristic composition, might reflect the latitudinal position of the former, which is influenced by the dense tropical rain forest on Precambrian terranes that is more common in this region (Fabris \& Cesar 1996; Assis et al. 2004a). However, this result should be interpreted with caution given the sensitivity of the correspondence analysis to species of low occurrence, and it is suggested that those be given less weight, because they can introduce noise and tend to contribute little to the patterns generated by the analysis (ter Braak 1995). Therefore, when species occurring in only one area were excluded from the analysis, the ordering pattern became conservative, even when species occurring in two, three or four areas were excluded (Fig. 6). Furthermore, the division of the restingas of southern and northern Espírito Santo into two floristic blocks became more evident, providing evidence of a historical separation that was probably caused by the influence of the surrounding vegetation on the floristic composition of the restinga.

In the ordination diagram, the muçununga forest in Linhares can be seen to be in close floristic proximity to the restingas and the influence of the mata alta on species composition in the muçununga forest is evident. The TWINSPAN confirmed this pattern of differentiation, allowing the identification of species responsible for the division between the muçununga forest and the mata alta. Those species include Andira nitida, Cupania emarginata, Eugenia astringens, G. brasiliensis, Myrcia splendens and Rhodostemonodaphne capixabensis, all of which are commonly found in the restingas of Espírito Santo (Pereira \& Araujo 2000). As in the similarity dendrogram, the muçununga forest in Caravelas, in southern Bahia, was found to be distant from all other forests in the ordination diagram, confirming that the species composition of the community is quite distinct from that of the others analyzed here.

The Itaúnas forest retains unique floristic characteristics because of many factors, among which is its high diversity. The floristic affinity between the Itaúnas restinga and tabuleiro forests revealed important floristic patterns, suggesting that the species composition of the restingas of Espírito Santo is a reflection of distinct environmental and geomorphological conditions, the surrounding vegetation having a decisive influence. This seems to be the main factor responsible for the gradual reduction in floristic similarities between the restingas of the north and south. In addition, the indication of preferential species generated by the TWINSPAN can inform the preparation of species lists used in environmental restoration programs, mainly in the restinga, given its naturally limiting conditions and the intense process of fragmentation that it is undergoing.

\section{Acknowledgments}

We are grateful to the staff of Itaúnas State Park for the logistical support provided throughout the process of conducting this study, to Elias Tadeu Claudionor for authorizing the fieldwork carried out on Jequitaia farm, and to the various experts consulted in order to determine the species, as well as to Ariane Luna Peixoto for critiquing the manuscript. This study received financial support in the form of grants from the Brazilian Conselho Nacional de Desenvolvimento Científico e Tecnológico (CNPq, National Council for Scientific and Technological Development; Young Investigator Grant to AG and a Research Productivity Grant to LFTM).

\section{References}

Amaral, D.D.; Prost, M.T.; Bastos, M.N.C.; Neto, S.V.C. \& Santos, J.U.M. 2008. Restingas do litoral amazônico, Estados do Pará e Amapá, Brasil. Boletim do Museu Paraense Emílio Goeldi 3(1): 35-67.

APG III. 2009. An update of the Angiosperm Phylogeny Group classification for the orders and families of flowering plants: APG III. Botanical Journal of the Linnean Society 161: 105-121.

Araujo, D.S.D. 2000. Análise florística e fitogeográfica das restingas do Estado do Rio de Janeiro. Tese de doutorado. Universidade Federal do Rio de Janeiro, Rio de Janeiro.

Ashton, P.S. 1988. Systematics and ecology of rain forest trees. Taxon 37(3): 622-629.

Assis, A.M.; Magnago, L.F.S.; \& Fernandes, H.Q.B. 2007. Floresta Estacional Semidecidual de Terras Baixas, Submontana e Montana. Pp. 51-54. In: Espécies da Flora Ameaçadas de Extinção no Estado do Espírito Santo. Simonelli, M. \& Fraga, C.N. (Orgs.). Vitória, IPEMA.

Assis, A.M.; Pereira, O.J. \& Thomaz, L.D. 2004a. Florística de um trecho de floresta de restinga no município de Guarapari, Espírito Santo, Brasil. Acta Botanica Brasilica 18(1): 191-201.

Assis, A.M.; Thomaz, L.D. \& Pereira, O.J. 2004b. Fitossociologia de uma floresta de restinga no Parque Estadual Paulo César Vinha, Setiba, município de Guarapari (ES). Revista Brasileira de Botanica 27(2): 349-361.

Assumpção, J. \& Nascimento, M.T. 2000. Estrutura e composição florística de quatro formações vegetais de restinga no complexo lagunar Grussaí/ Iquipari, São João da Barra, RJ, Brasil. Acta Botanica Brasilica 14: 301-315.

Brower, J.E. \& Zar, J.H. 1984. Field \& laboratory methods for general ecology. Boston, W.C. Brown Publishers.

Brummitt, R.K. \& Powell, C.E. (Eds.). 1992. Authors of Plant Names. Kew, Royal Botanic Gardens.

Colwell, R.K.; Mao, C.X. \& Chang, J. 2004. Interpolating, extrapolating, and comparing incidence-based species accumulation curves. Ecology 85(10): 2717-2727.

Dorneles, L.P.P. \& Waechter, J.L. 2004. Estrutura do componente arbóreo da floresta arenosa de restinga do Parque Nacional da Lagoa do Peixe, Rio Grande do Sul. Hoehnea 31(1): 61-71.

Fabris, L.C. \& César, O. 1996. Estudos florísticos em uma mata litorânea no sul do Estado do Espírito Santo. Boletim do Museu de Biologia Mello-Leitão (Nova Série) 5: 15-46.

Fidalgo, O. \& Bononi, V.L. 1984. Técnicas de coleta, preservação e herborização de material botânico. São Paulo, Instituto de Botânica.

Franklin, J.F.; Shugart, H.H. \& Harmon, M.E. 1987. Tree death as an ecological process. BioScience 37: 550-556.

Freire, M.S.B. 1990. Levantamento florístico do Parque Estadual das Dunas de Natal. Acta Botanica Brasilica 4: 41-59.

Guedes, D.; Barbosa, L.M. \& Martins, S.E. 2006. Composição florística e estrutura fitossociológica de dois fragmentos de floresta de restinga no Município de Bertioga, SP, Brasil. Acta Botanica Brasilica 20(2): 299-311.

Hammer, Ø.; Harper, D.A.T. \& Ryan, P.D. 2001. PAST: Paleontological Statistics Software Package for Education and Data Analysis. Palaeontologia Electronica 4(1): 1-9. 
Hill, M.O. 1979. TWINSPAN: a FORTRAN program for arranging multivariate data in an ordered twoway table by classification of the individuals and attributes. Ithaca, Cornell University.

IBGE (Instituto Brasileiro de Geografia e Estatística). 1992. Manual Técnico da Vegetação Brasileira. Série Manuais Técnicos em Geociências, Rio de Janeiro.

Jesus, R.M. \& Rolim, S.G. 2005. Fitossociologia da Mata Atlântica de Tabuleiro. Boletim Técnico da Sociedade de Investigações Florestais 19: 1-149.

Kent, M. \& Coker, P. 1992. Vegetation description analyses. London, Behaven Press.

Kersten, R.A. \& Galvão, F. 2011. Suficiência amostral em inventários florísticos e fitossociológicos. Pp. 156-173. In: Felfili, J.M.; Eisenlohr, P.V.; Melo, M.M.R.F.; Andrade, L.A. \& Meira-Neto, J.A.A. (Eds.). Fitossociologia do Brasil: Métodos e Estudos de Caso. v.1, Viçosa, Editora da Universidade Federal de Viçosa.

Kovach, W.L. 2004. Multivariate Statistical Package for Windows, version 3.1. Pentraeth, Wales, Kovach Computing Services.

Lani, J.L.; Resende, M.; Rezende, S.B. \& Feitoza, L.R. (Eds.). 2008. Atlas de Ecossistemas do Espírito Santo. Viçosa, SEMA, Editora GSA.

Leitão-Filho, H.F. 1987. Considerações sobre a florística de florestas tropicais e sub-tropicais do Brasil. IPEF 35: 41-46.

Lobão, A.Q. \& Kurtz, B.C. 2000. Fitossociologia de um trecho de mata de restinga na Praia Gorda, Município de Armação de Búzios, Rio de Janeiro. Pp. 66-73. In: Anais do V Simpósio de Ecossistemas Brasileiros: conservação. São Paulo, ACIESP.

Magurran, A.E. 2004. Measuring biological diversity. Oxford, Blackwell Publishing Company.

Marques, M.C.M.; Swaine, M.D. \& Liebsch, D. 2011. Diversity distribution and floristic differentiation of the coastal lowland vegetation: implications for the conservation of the Brazilian Atlantic Forest. Biodiversity \& Conservation 20: 153-168.

Martin, L.; Bittencourt, A.C.S.P. \& Vilas-Boas, G.S. 1981. Différenciation sur photographies aériennes des terrasses sableuses marines pléistocènes et holocènes du littoral de létat de Bahia (Brésil). Photointerprétation 20(3): 1-10.

Martin, L.; Suguio, K.; Domingues, J.M.L. \& Flexor, J.M. 1997. Geologia do Quaternário costeiro do Litoral Norte do Rio de Janeiro e Espírito Santo. Belo Horizonte, CPRM/FAPESP.

McCune, B. \& Grace, J.B. 2002. Analysis of Ecological Communities. Gleneden Beach, MjM Software Design.

McCune, B. \& Mefford, M.J. 1999. PC-ORD. Multivariate analysis of ecological data, version 4.10. Gleneden Beach, MjM software Design.

Meira-Neto, J.A.; Souza, A.L.; Lana, J.M. \& Valente, G.E. 2005. Composição florística, espectro biológico e fitofisionomia da vegetação de muçununga nos Municípios de Caravelas e Mucuri, Bahia. Revista Árvore 29(1): 139-150.

Menezes, L.F.T. \& Araujo, D.S.D. 2005. Formações vegetais da Restinga da Marambaia. Pp. 67-120. In: Menezes, L.F.T.; Peixoto, A.L. \& Araujo, D.S.D. (Orgs.). História Natural da Marambaia. Seropédica, Editora da Universidade Federal Rural do Rio de Janeiro.

Menezes, L.F.T.; Araujo, D.S.D. \& Nettesheim, F.C. 2010. Estrutura comunitária e amplitude ecológica do componente lenhoso de uma floresta de restinga mal drenada no sudeste do Brasil. Acta Botanica Brasilica 24(3): 825-839.

Müeller-Dombois, D. \& Ellenberg, H. 1974. Aims and methods of vegetation ecology. New York, J. Wiley \& Sons.

Oliveira-Filho, A.T. \& Fontes, M.A.L. 2000. Patterns of floristic differentiation among Atlantic forests in Southeastern Brazil and the influence of climate. Biotropica 32: 793-810.

Paula, A. de \& Soares, J.J. 2011. Estrutura horizontal de um trecho de floresta ombrófila densa das terras baixas na Reserva Biológica de Sooretama, Linhares, ES. Floresta 41(2): 321-334.

Peixoto, A.L. \& Silva, I.M. 1997. Tabuleiro forests of Northern Espirito Santo, South-eastern Brazil. Pp. 369-372. In: Davis, S.D.; Heywood, V.H.; Herrera-Macbryde, O.; Villa-Lobos, J. \& Hamilton, A.C. (Eds.). Centres of Plant Diversity: a guide and strategy for their conservation. Cambrige, IUCN Publications Unit.
Peixoto, A.L.; Silva, I.M.; Pereira, O.J.; Simonelli, M.; Jesus, R.M. \& Rolim, S.G. 2008. Tabuleiro Forests North of Rio Doce: Their representation in the Vale do Rio Doce Natural Reserve, Espírito Santo, Brazil. Memoirs of the New York Botanical Garden 100: 319-350.

Pereira, O.J. \& Araujo, D.S.D. 2000. Análise florística das restingas dos Estados do Espírito Santo e Rio de Janeiro. Pp. 25-63. In: Esteves, F.A. \& Lacerda, L.D. (Eds.). Ecologia de Restingas e Lagoas Costeiras. Macaé, NUPEM/UFRJ.

Pereira, O.J. \& Gomes, J.M.L. 1994. Levantamento florístico das comunidades vegetais de restinga no município de Conceição da Barra/ES. Pp. 67-78. In: Anais III Simpósio de Ecossistemas da Costa da Costa Sul e Sudeste Brasileira: subsídios a um gerenciamento ambiental. São Paulo, ACIESP.

Pereira, O.J. \& Zambom, O. 1998. Composição florística da restinga de Interlagos, Vila Velha (ES). Pp. 129-139. In: Anais do IV Simpósio de Ecossistemas Brasileiros. São Paulo, ACIESP.

Pereira, O.J. 1990. Caracterização fitofisionômica da restinga de Setiba, Guarapari, Espírito Santo. Pp. 207-219. In: Anais do II Simpósio de Ecossistemas da Costa Sul e Sudeste Brasileira: estrutura, função e manejo. São Paulo, ACIESP.

Pereira, O.J.; Assis, A.M. \& Souza, R.L.D. 1998. Vegetação da restinga de Pontal do Ipiranga, Município de Linhares (ES). Pp. 117-128. In: Anais do IV Simpósio de Ecossistemas Brasileiros. São Paulo, ACIESP.

Pimentel, M.C.P.; Barros, M.J.; Cirne, P.; Mattos, E.A.; Oliveira, R.C.; Pereira, M.C.A.; Scarano, F.R.; Zaluar, H.L.T. \& Araujo, D.S.D. 2007. Spacial variation in the structure and floristic composition of "restinga" vegetation in southeastern Brazil. Revista Brasileira de Botânica 30(3): 543-551.

Rolim, S.G.; Ivanauskas, N.M.; Rodrigues, R.R.; Nascimento, M.T.; Gomes, J.M.L.; Folli, D.A. \& Couto, H.T.Z. 2006. Composição Florística do estrato arbóreo da Floresta Estacional Semidecidual na Planície Aluvial do rio Doce, Linhares, ES, Brasil. Acta Botanica Brasilica 20(3): 549-561.

Sá, C.F.C. \& Araujo, D.S.D. 2009. Florística e estrutura de uma floresta de restinga em Ipatingas, Saquarema, Rio de Janeiro, Brasil. Rodriguésia 60(1): 147-170.

Sacramento, A.C.; Zickel, C.S. \& Almeida Jr., E.B. 2007. Aspectos florísticos da vegetação de restinga no litoral de Pernambuco. Revista Árvore 31: 1121-1130.

Salomão, A.L.F. 1998. Subsídios técnicos para a elaboração do plano de manejo da Floresta Nacional do Rio Preto - ES. Tese de doutorado. Universidade Federal de Viçosa, Minas Gerais.

Santos-Filho, F.S.; Almeida-Jr. E.B.; Bezerra, L.F.M.; Lima, L.F. \& Zickel, C.S. 2011. Magnoliophyta, restinga vegetation, state of Ceará, Brazil. Check List 7(4): 478-485.

Scarano, F.R. 2002. Structure, function and floristic relationships of plant communities in stressful habitats marginal to the Brazilian Atlantic rain forest. Annals of Botany 90: 517-524.

Scherer, A.; Maraschin-Silva, F. \& Baptista, L.R.M. 2005. Florística e estrutura do componente arbóreo de matas de restinga arenosa no Parque Estadual de Itapuã, RS, Brasil. Acta Botanica Brasilica 19(4): 717-727.

Silva, S.M. \& Britez, R.M. 2005. A vegetação da Planície Costeira. Pp. 4984. In: Marques, M.C.M. \& Britez, R.M. (Orgs.). História Natural e conservação da Ilha do Mel. Curitiba, Editora da Universidade Federal do Paraná.

Simonelli, M.; Souza, A.L.; Peixoto, A.L. \& Silva, A.F. 2008. Floristic Composition and Structure of the Tree Component of a Muçununga Forest in the Linhares Forest Reserve, Espírito Santo, Brasil. Memoirs of the New York Botanical Garden 100: 251-370.

Souza, A.L.; Meira-Neto, J.A.A. \& Schettino, S. 1998. Avaliação florística, fitossociológica e paramétrica de um fragmento de floresta Atlântica secundária, Município de Caravelas, Bahia. Documento Sociedade de Investigações Florestais, 19. Universidade Federal de Viçosa, Minas Gerais.

Suguio, K. \& Martin, L. 1978. Quaternary marine formations of the state of São Paulo and southern Rio de Janeiro. In: International Symposium on Coastal Evolution in the Quaternary. Special Publication, São Paulo, IGCP/SBG. 
Suguio, K.; Martin, L. \& Dominguez, J.M.L. 1982. Evolução do delta do rio Doce (ES) durante o Quaternário: Influência das variações do nível do mar. Pp. 93-116. In: Suguio, K.; Meis, M.R.M. \& Tessler, M.G. (Eds.). Atas IV Simpósio Quaternário do Brasil. Sociedade Brasileira de Geologia, Rio de Janeiro.

Tabarelli, M. \& Mantovani, W. 1997. Colonização de clareiras naturais na floresta atlântica do Sudeste do Brasil. Revista Brasileira de Botânica 20(1): 57-66.

ter Braak, C.J.F. 1995. Ordination. Pp. 91-173. In: Jongman, R.H.G.; ter Braak, C.J.F. \& van Tongeren O.F.R. (Eds.). Data analysis in community and landscape ecology. Cambridge, Cambridge University Press.

Trindade, A. 1991. Estudo florístico e fitossociológico do estrato arbustivo-arbóreo de um trecho de floresta arenícola costeira do Parque Estadual das Dunas, Natal, RN. Dissertação de mestrado. Universidade Federal Rural de Pernambuco, Recife.

Waechter, J.L.; Müller, S.C.; Breier, T.B. \& Venturi, S. 2000. Estrutura do componente arbóreo em uma floresta subtropical de planície costeira interna. Pp. 92-112. In: Anais do V Simpósio Brasileiro de Ecossistemas. Espírito Santo, ACIESP. 